\title{
The Leiognathus splendens complex (Perciformes: Leiognathidae) with the description of a new species, Leiognathus kupanensis Kimura and Peristiwady
}

\author{
Seishi Kimura ${ }^{\circledR}$, Takahiro Ito ${ }^{1}$, Teguh Peristiwady ${ }^{2}$, Yukio Iwatsuki ${ }^{3}$, Tetsuo Yoshino ${ }^{4}$, \\ and Paul V. Dunlap ${ }^{5}$ \\ ${ }^{1}$ Fisheries Research Laboratory, Mie University, P. O. Box 11, Wagu, Shima, Mie 517-0703, Japan \\ (e-mail: SK, kimura-s@bio.mie-u.ac.jp) \\ ${ }^{2}$ Coral Reef Information and Training Centre, Bappeda NTT, Jl. Polisi Militer 2, Kupang, NTT, Indonesia \\ (e-mail: ikan_teguh@yahoo.com) \\ ${ }^{3}$ Division of Fisheries Sciences, Faculty of Agriculture, Miyazaki University, 1-1 Gakuen-kibanadai-nishi, Miyazaki 889-2192, \\ Japan (e-mail: yuk@cc.miyazaki-u.ac.jp) \\ ${ }^{4}$ Department of Marine Sciences, Faculty of Science, University of the Ryukyus, 1 Senbaru, Nishihara, Okinawa 903-0213, Japan \\ (e-mail:b985005@sci.u-ryukyu.ac.jp) \\ ${ }_{5}^{5}$ Department of Ecology and Evolutionary Biology, University of Michigan, 830 North University Avenue, Ann Arbor, \\ MI 48109-1048, USA (e-mail: pvdunlap@umich.edu)
}

Received: November 4, 2004 / Revised: March 13, 2005 / Accepted: March 20, 2005

\section{Ichthyological Research \\ (C) The Ichthyological Society of Japan 2005}

Ichthyol Res (2005) 52: 275-291

DOI $10.1007 / \mathrm{s} 10228-005-0283-5$

\begin{abstract}
Taxonomic analysis of a group of morphologically similar ponyfishes (Perciformes: Leiognathidae) establishes the Leiognathus splendens complex comprising four valid species: L. jonesi James, 1971, widely distributed in the Indo-West Pacific, from Mauritius to Papua New Guinea, north to Hainan I. (China), and south to Brisbane, Australia; L. kupanensis sp. nov., currently known only from Kupang, Timor, Indonesia; L. rapsoni Munro, 1964, currently known only from India, Indonesia, and Papua New Guinea, and L. splendens Cuvier, 1829, widely distributed in the eastern Indian and western Pacific oceans, from India to Papua New Guinea, and from southern Japan to northern Australia. The L. splendens complex can be defined by the following combination of characters: body depth $42-60 \%$ of standard length; mouth protruding downward; slender, minute teeth uniserially on jaws; lower margin of orbit above the horizontal through the gape when mouth closed; breast almost completely scaled; lateral line complete, and a dark blotch on top of spinous dorsal fin. Diagnostic characters of the members are as follows: L. jonesi-anterior dorsolateral body surface with a semicircular naked area on nape, and a paler dark blotch on spinous dorsal fin; L. kupanensis-anterior dorsolateral body surface widely naked; L. rapsoni — cheek scaled; L. splendens — anterior dorsolateral body surface completely scaled and a jet black blotch on spinous dorsal fin.
\end{abstract}

Key words Leiognathidae $\cdot$ Leiognathus jonesi $\cdot$ Leiognathus kupanensis sp. nov. $\cdot$ Leiognathus rapsoni $\cdot$ Leiognathus splendens
$\mathrm{T}$ he Indo-Pacific leiognathid fishes belonging to the genus Leiognathus, characterized by a forward- or downward-protruding mouth and small or minute teeth on jaws, have long been confused taxonomically because of their similar body shape, almost entirely silvery body coloration, and overlapping meristics. Our recent revisional study of the Leiognathus aureus complex (Kimura et al., 2003a), however, has resulted in the redescription of Leiognathus aureus Abe and Haneda, 1972, and Leiognathus hataii Abe and Haneda, 1972, and the description of Leiognathus panayensis Kimura and Dunlap in Kimura et al., 2003a. Here we examine and resolve the taxonomic status of another group of morphologically very similar leiognathids, referred to as the "Leiognathus splendens complex," which is composed of Leiognathus splendens (Cuvier, 1829), Leiognathus rapsoni Munro, 1964, Leiognathus jonesi James, 1971, and a new species. These fishes share the following combination of characters: a dark blotch on top of spinous dorsal fin, breast almost fully scaled, and lower margin of orbit above the horizontal through the gape when mouth closed.

In this species complex, the oldest nominal species is $L$. splendens, which was named by Cuvier (1829) as Equula splendens in a footnote in "Règne Animal," based on a description and drawing given by Russell (1803). Valenciennes in Cuvier and Valenciennes (1835) described Equula gomorah based on the specimens collected from India and Red Sea, but Day (1876) synonymized the species under E. splendens. Subsequently, Equula ovalis De Vis, 1884 and Equula simplex De Vis, 1884, from northern 
Australia, Leiognathus philippinus Fowler, 1918, from the Philippines, and L. rapsoni Munro, 1964, from Papua New Guinea were described. James (1971) described L. jonesi on the basis of the specimens from India; subsequently, in his revisory work on the family Leiognathidae (James, 1978), he recognized $L$. splendens and $L$. jonesi as valid species, synonymizing $E$. gomorah and $L$. philippinus under $L$. splendens. Fowler (1904) described Leiognathus spilotus, based on the specimen collected from Sumatra, Indonesia. This species had once been suggested to be a junior synonym of Leiognathus blochii (Valenciennes in Cuvier and Valenciennes, 1835) by Weber and de Beaufort (1931). Although Leiognathus indicus Singh and Talwar, 1978, was described from specimens collected from the Bay of Bengal (India), the validity of this species has not been discussed; no other specimens have been reported and the literature contains no further reference to this species. Subsequently, Jones (1985) carried out a revision of Australian leiognathids and treated E. ovalis, E. simplex, and L. jonesi as junior synonyms of $L$. splendens. Jones (1985) also recognized $L$. rapsoni as a valid species, despite its absence from Australian waters, but did not refer L. indicus. Therefore, in accordance with Jones (1985), the Leiognathus splendens complex has been thought to contain only two valid species, L. splendens and L. rapsoni.

In the present account, we have revised the $L$. splendens complex based on the examination of many specimens collected from a variety of locations throughout Indo-West Pacific. We recognize four species in this complex: L. jonesi, $L$. rapsoni, and $L$. splendens, which are redescribed here, and a newly described species, Leiognathus kupanensis.

\section{Materials and Methods}

Counts and measurements generally followed Hubbs and Lagler (1947) and Kimura et al. (2003a). Additional measurements include widths of second spines of dorsal and anal fins, which were measured bilaterally as horizontal widths at the level of the tip of the first spines when fins were extended so that spines were perpendicular to fin bases. All measurements were made with a digital caliper to the nearest $0.01 \mathrm{~mm}$. Cyanine blue was used to examine and count scales. Osteological observation was made from soft $\mathrm{X}$-ray photos and from cleared and stained specimens. Standard and head lengths are abbreviated as SL and HL, respectively. Institutional codes follow Leviton et al. (1985) with additional abbreviations as follows: MUFS, Division of Fisheries Sciences, Faculty of Agriculture, Miyazaki University, Miyazaki, Japan; SFU, Shanghai Fisheries University, Shanghai, China; ZRC, Raffles Museum of Biodiversity Research, Department of Biological Sciences, National University of Singapore.

\section{The Leiognathus splendens Complex}

Diagnosis. A species group of the genus Leiognathus as defined by the following combination of characters: body
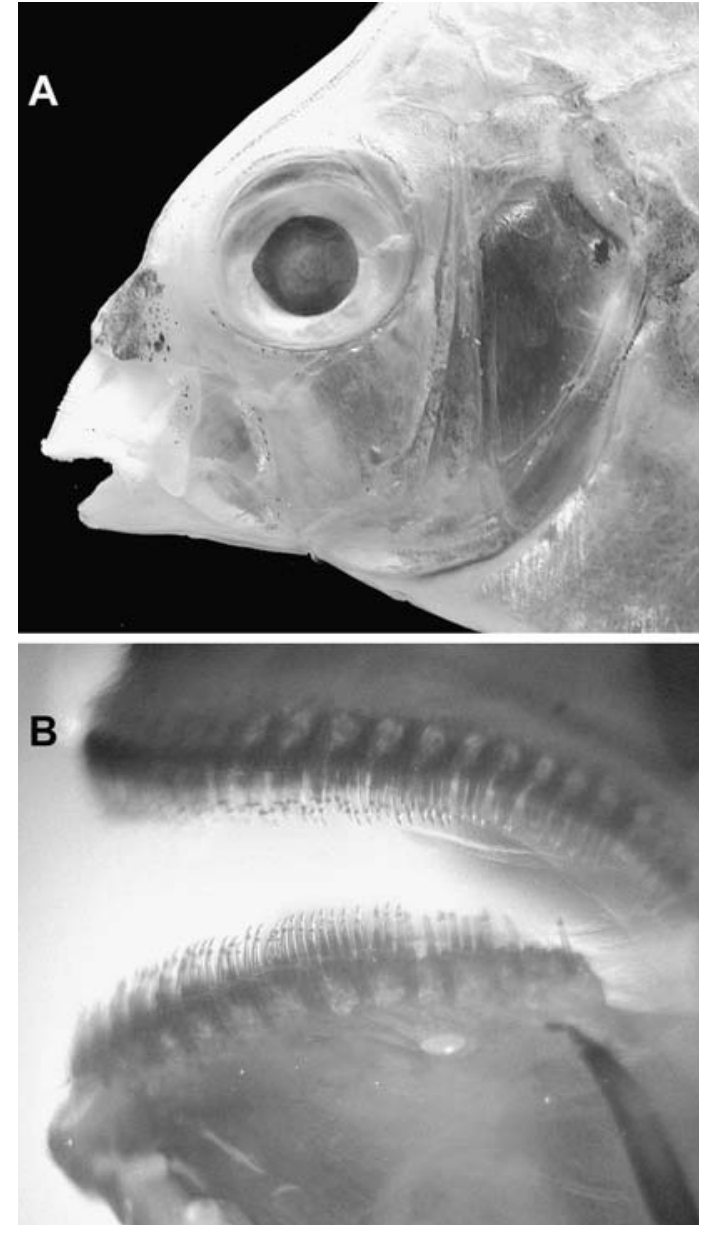

Fig. 1. A Head of Leiognathus splendens, MUFS 16917, 62 mm SL. B Jaw teeth of L. jonesi, FRLM 30062, $70 \mathrm{~mm} \mathrm{SL}$

deep, body depth 42-60\% SL; mouth protruding downward (Fig. 1A); jaw teeth slender, minute (Fig. 1B); lower margin of orbit above the horizontal through the gape when mouth closed; breast almost completely scaled; lateral line complete; dark blotch on top of spinous dorsal fin.

Description. Characters given in the diagnosis are not repeated. Body strongly compressed, dorsal profile convex, similar to or somewhat more strongly so than ventral; mouth subterminal, gape almost horizontal; snout blunt, anteroventral profile of lower jaw almost straight or weakly concave; vomer and palatines toothless; lateral ethmoid bearing a small forked spine on dorsal end, just anterior to supraorbital ridge; tip of posterior limb of maxilla exceeding beyond the vertical through anterior margin of eye; lower edge of preopercle serrated; corner of preopercle rounded; gill rakers 5-7 + 18-24; two small papillae on rear edge of gill cavity supported by cleithrum; scales small covering most of body; lateral line complete, with 46-66 scales; a single dorsal fin with usually VIII, 16, anal fin usually III, 14, the second spines of both fins longest; third and forth dorsal and third anal fin spines serrated proximally along anterior margin; anal fin spines more slender than those of dorsal fin; pelvic fins I, 5; with paired axillary scalelike process; caudal fin forked; vertebrae $10+14=24$; tip of neural and hemal 
spines of fifth preural centrum pointed, but those of fourth preural centrum expanded, flattened; first to fourth hypurals forming two plates (first + second and third + fourth); ribs 7 , epipleurals 13; a single supraneural; middle pterygiophores of dorsal and anal fin soft rays with pair of exposed retrorse sharp spines on outer edge.

Light organ morphologically similar in all species of the complex; single, internal, circumesophageal, inflated or anteroventrally/posterodorsally compressd torus, flesh colored with black and black spot-embedded white sheath over ventral half; visible internally as a flattened surface at anterior end of gasbladder; lateral lobes not enlarged; sexually dimorphic in Leiognathus splendens, volume 1.6 to 3 times greater in males compared to similarly sized females (McFall-Ngai and Dunlap, 1984); light organ shape and pigmentation and gasbladder lining not dimorphic; external dimorphism (male-specific or male-enhanced external skin patches) not present; volume dimorphism of light organ probable in L. rapsoni (ca. $49 \mathrm{~mm}^{3}$ in UMMZ 243702-1, male, $81 \mathrm{~mm} \mathrm{SL}$; ca. $6.5 \mathrm{~mm}^{3}$ in UMMZ 243702-2, possible female, $65 \mathrm{~mm} \mathrm{SL}$ ), and likely in $L$. jonesi and $L$. kupanesis sp. nov. but present material insufficient for determination.

\section{Key to the Species}

1a. Cheek naked (Fig. 2A,B,D); interspace of pelvic keels naked (Fig. 3A,B,E) . . . . . . . . . . . . . . . . 2

1b. Cheek scaled (Fig. 2C); interspace of pelvic keels scaled (Fig. 3C,D) . . . . . . ......... Leiognathus rapsoni

2a. Anterior dorsolateral surface of body widely naked (Fig. 2B) .......... Leiognathus kupanensis sp. nov.

2b. Anterior dorsolateral surface of body almost entirely scaled (Fig. 2A,C,D) .....................

3a. Dark blotch on dorsal fin paler, dark gray (Fig. 4A-C); nape with a semicircular naked area (Fig. 2A); second spines of dorsal and anal fins weak, slender (width of second spines of dorsal and anal fins $0.72-1.1 \%$ of SL and $0.60-0.95 \%$ of SL, respectively; Fig. 5$)$.......... ....................... Leiognathus jonesi

3b. Dark blotch on dorsal fin jet black (Fig. 4D); nape without a semicircular naked area (Fig. 2D); second spines of dorsal and anal fins robust (width of second spines of dorsal and anal fins $0.87-1.6 \%$ of SL and $0.76-1.7 \%$ of SL, respectively; Fig. 5) ....... Leiognathus splendens

\section{Leiognathus jonesi James, 1971 \\ (New English name: Jones' pony fish)}

(Fig. 6, Table 1)

Leiognathus jonesi James, 1971; 316-319 (type locality: Palk Bay, Tamil Nadu, India); James, 1978: 149-151 (Palk Bay, Tamil Nadu, India); Iwatsuki et al., 2000: 100 (listed only, Makassar, Sulawesi, Indonesia).

Leiognathus splendens (not of Cuvier); Zheng, 1962: 446-447 (Hainan I., China); Kühlmorgen-Hille, 1974: LEIOG Leiog 10 (in part, Eastern Indian Ocean and Western Central pacific); Gloerfelt-Tarp and Kailola, 1984: 171 (Java, Indonesia); Mohsin and Ambak, 1996: 349350, fig. 256 (Malaysia); Mansor et al., 1998: 158, fig. 157 (South China

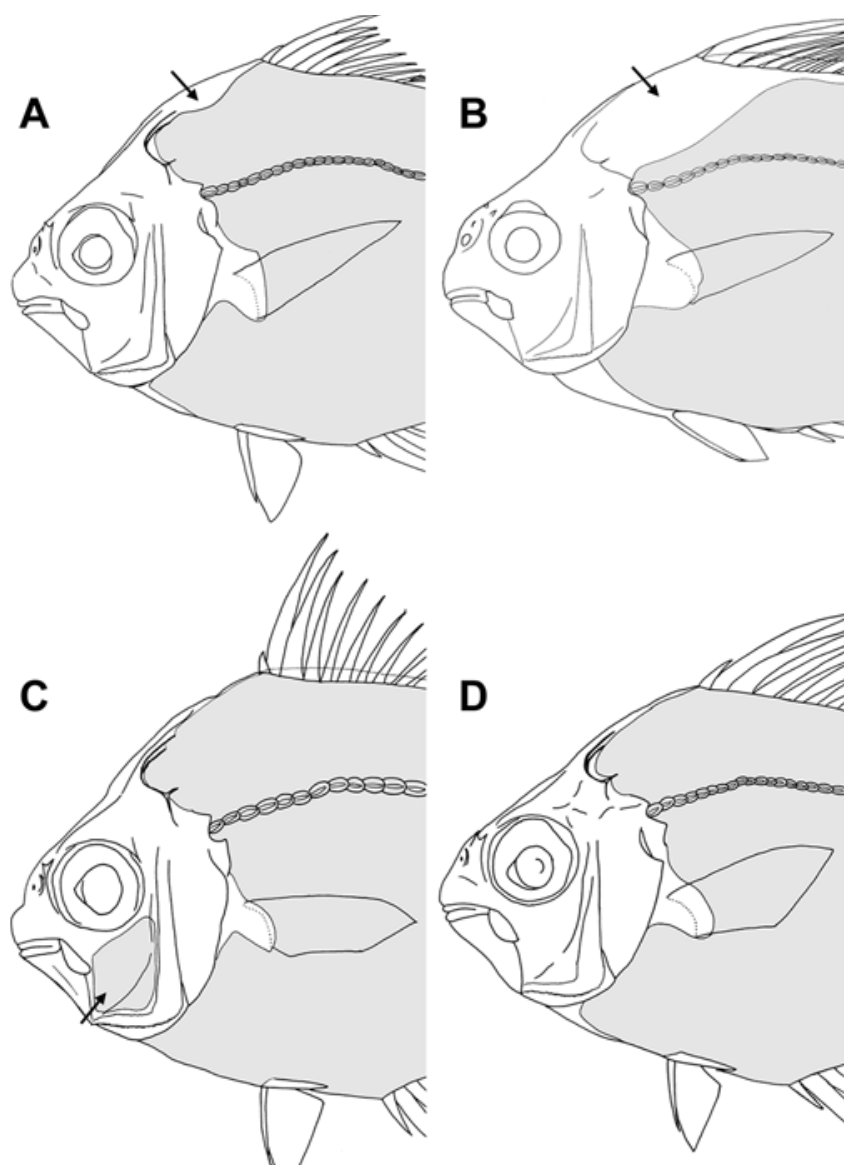

Fig. 2. Cheek and anterior part of body; scaled area shaded. A Leiognathus jonesi, FRLM 28686, 73 mm SL. Arrow indicates a semicircular naked area on nape. B Leiognathus kupanensis, holotype, NSMTP 69427, $80 \mathrm{~mm} \mathrm{SL}$. Arrow indicates a wide naked area on anterior dorsolateral surface of body. C Leiognathus rapsoni, FRLM 16699, $64 \mathrm{mmSL}$. Arrow indicates a scaled area on cheek. D Leiognathus splendens, MUFS 16920, $61 \mathrm{~mm} \mathrm{SL}$

Sea); Woodland et al., 2001: 2815 (in part, Western Central Pacific); Fish Team of the Trang Project, 2002: 14, fig. 59 (Trang, Thailand).

Non-type materials. 99 specimens, 33-139 mm SL. CAS SU 69867, $50 \mathrm{~mm}$ SL, Vizagapatam, Chennai, India; CAS SU 37222, $72 \mathrm{~mm}$ SL, Mergui Archipelago, Myanmar; CAS SU 69868 (2 specimens), 43$47 \mathrm{~mm}$ SL, Calicut, Kerala, India; FAKU 103832, $68 \mathrm{~mm}$ SL, Port Luis, Mauritius; FAKU 110585, 103 mm SL, Bay of Thailand, FRLM 16700, $78 \mathrm{~mm}$ SL, Kuta, Lombok, Indonesia; FRLM 16993-16996, 17008, 17009, 20392, 20404, 9 specimens, 84-109 mm SL, Tanjung Luar, Lombok, Indonesia; FRLM 21493, 21495, 21498, 21628, 4 specimens, 80-101 mm SL, Passo, Ambon, Indonesia; FRLM 28682, 28683, 28685 28695, 11 specimens, 73-88 mm SL, Phuket, Thailand; MUFS 9344, 9345, 2 specimens, 72-75 mm SL, Iloilo, Panay, Philippines; MUFS 14468, 14506-14518, 14 specimens, Hat Yai, Thailand; MUFS 22485-22489, 5 specimens, $52-67 \mathrm{~mm}$ SL, Makassar, Sulawesi, Indonesia; NSMT-P 54716 (4), 55138, 60719, 60721-60723, 60733, 10 specimens, 61-94 mm SL, Sanya Bay, Hainan, China; SFU 3855, $90 \mathrm{~mm}$ SL, Hainan, China; UMMZ 213558, $74 \mathrm{~mm}$ SL, Phuket, Thailand; UMMZ 219157 (4), 219520, 219600 (3), 219610, 219711 (2), 219740, 220067, 220288 (2), 226772, 227346 (3), 19 specimens, 33-114 mm SL, mouth of Mekong River, Vietnam; UMMZ 224912 (3), 73-83 mm SL, off Pattaya, 

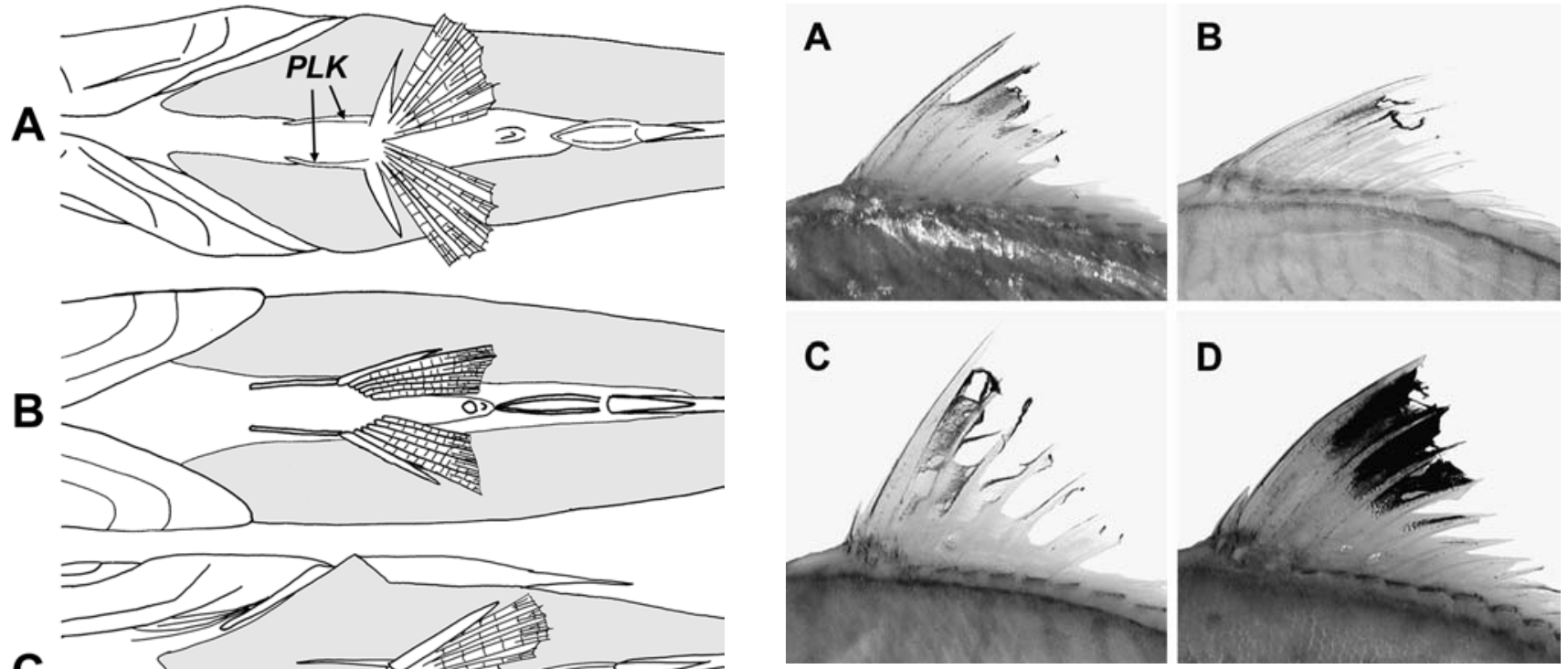

Fig. 4. Dark blotch on the tip of spinous dorsal fin. A Leiognathus jonesi, MUFS 14518, $48 \mathrm{~mm} \mathrm{SL}$. B Leiognathus kupanensis, holotype, NSMT-P 69427, 80 mmSL. C Leiognathus rapsoni, FRLM 16699, $64 \mathrm{~mm}$ SL. D Leiognathus splendens, MUFS 16916, $68 \mathrm{mmSL}$

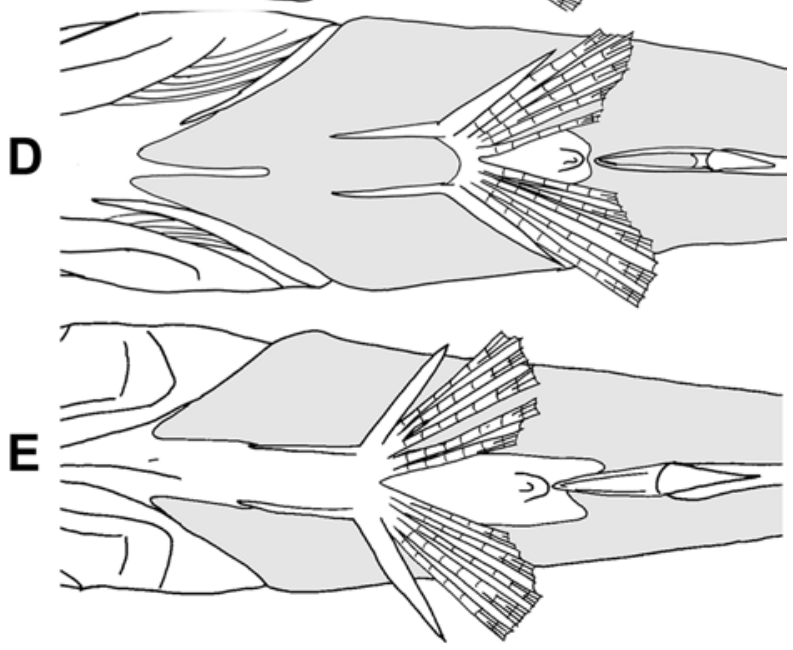

Fig. 3. Ventral surface of anterior body; scaled area shaded. A Leiognathus jonesi, FRLM 28691,75 mm SL. B Leiognathus kupanensis, holotype, NSMT-P 69427, $80 \mathrm{~mm}$ SL. C Leiognathus rapsoni, UMMZ 243702-2, 65 mm SL. D Leiognathus rapsoni, FRLM 15720, 66 mm SL. E Leiognathus splendens, MUFS 16917, 62 mm SL. PLK, pelvic keels

Thailand; UMMZ 226379 (2), 109-114mm SL, Penang, Malaysia; UMMZ 235095 (2), 102-108 mm SL, Kota Kinabalu, Sabah, Borneo Malaysia; URM-P 9277, 27425, 27426, 3 specimens, 75-139, Phuket, Thailand; ZRC 1332 (2), 98-103 mm SL, off Sarawaku, Borneo, Malaysia; ZRC 2717 (3), 37-53 mm SL, Berih, Singapore.

Materials for distributional records. 139 specimens, $26-100 \mathrm{~mm}$ SL. FRLM 30062, 70 mm SL, Phuket, Thailand; FRLM 30474-30482, 9 specimens, 65-98 mm SL, Hua Hin, Thailand; FRLM 30483, 60 mm SL, Bang Phe, Thailand; FRLM 30493-30496, 4 specimens, 47-67 mm SL, Pran Buri, Thailand; FRLM 30771-30779, 8 specimens, 68-91 mm SL, Iloilo, Panay, Philippines; MUFS 15013, 15127-15129, 15274-15286, 17 specimens, 40-91 mm SL, Bangsapanoi, Thailand; NSMT-P 57234, $65 \mathrm{~mm}$ SL, Rayong, Thailand; NSMT-P 65883, $60 \mathrm{~mm}$ SL, Long Chau Bay, Vietnam; NSMT-P 65884, 67899 (6), 67901, 67910, 9 specimens, 6189 mm SL, Cat Ba, Haiphong, Vietnam; NSMT-P 67896, 67905, 67906,

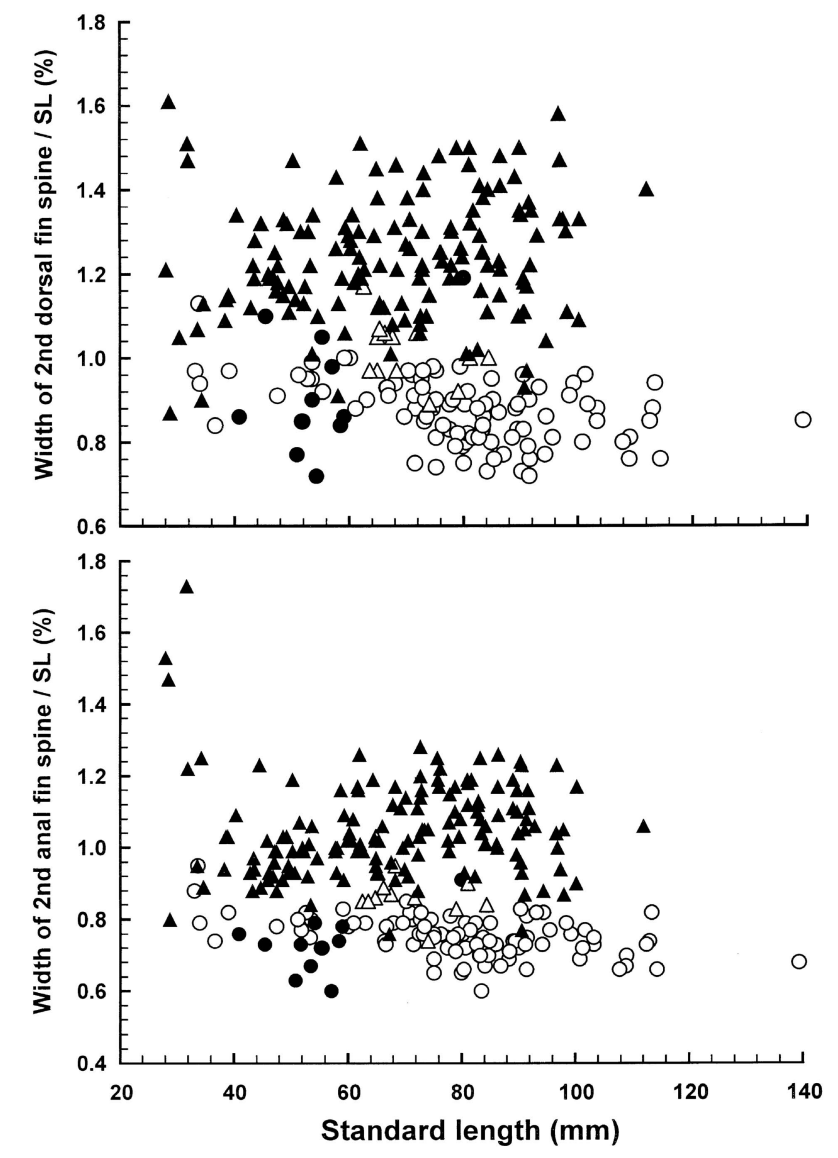

Fig. 5. Proportions of widths of second dorsal and anal fin spines in Leiognathus jonesi (open circles), L. kupanensis sp. nov. (solid circles), L. rapsoni (open triangles), and L. splendens (solid triangles) 


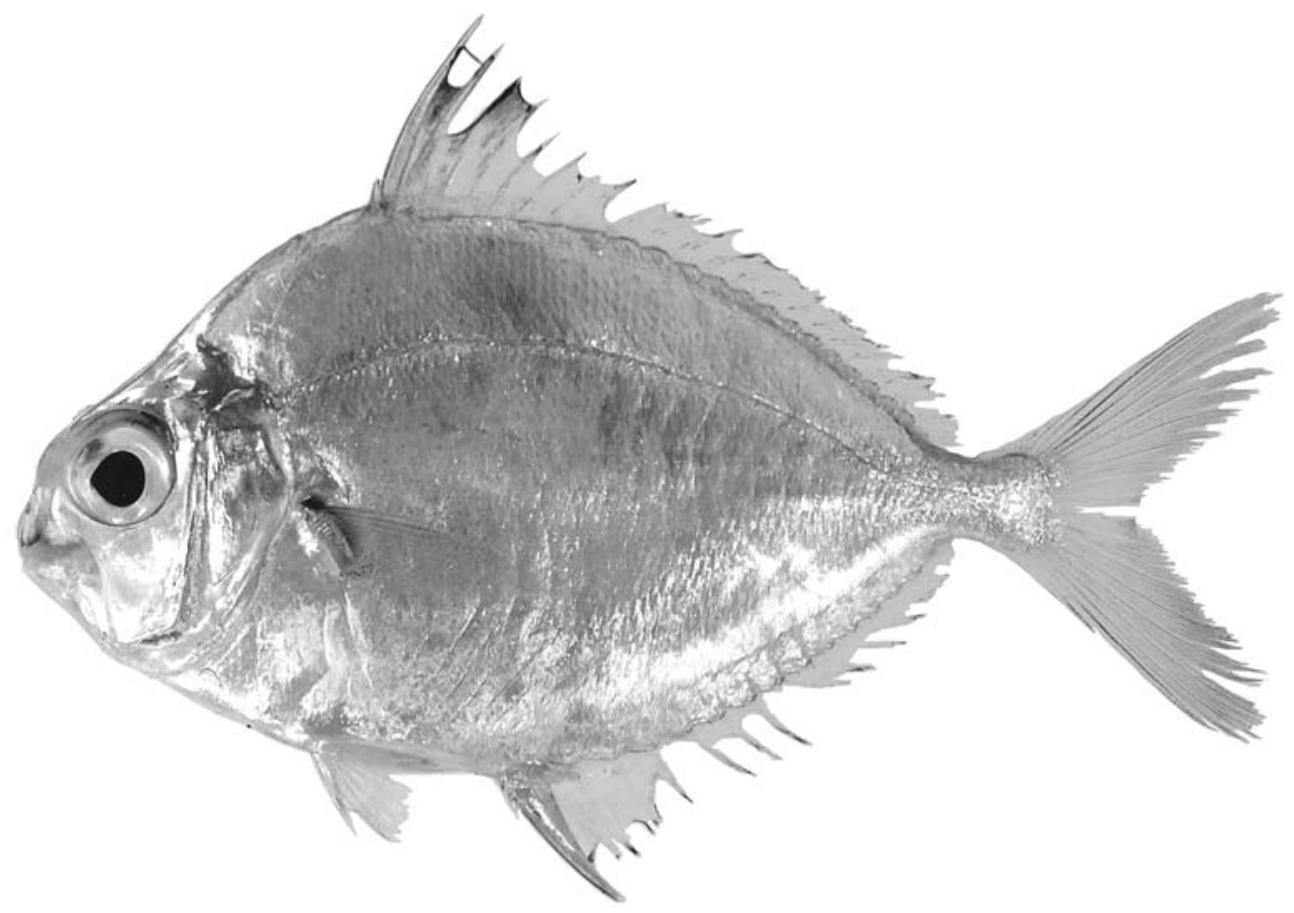

Fig. 6. Non-type material of Leiognathus jonesi, FRLM 20392, $89 \mathrm{~mm} \mathrm{SL}$, from Lombok, Indonesia

67909, 67916 (10), 14 specimens, 64-100 mm SL, Nha Trang, Vietnam; UMMZ 221933 (13), 74-84 mm SL, mouth of Mekong River, Vietnam; UMMZ 237293 (24), 26-47 mm SL, Songkhla, Thailand, URM-P 91309136, 7 specimens, 73-80 mm SL, Phuket, Thailand; URM-P 12538, $66 \mathrm{~mm}$ SL, Songkhla, Thailand; URM-P 14350, $66 \mathrm{~mm}$ SL, Ranong, Thailand; YCM-HLP 211, 671, 2 specimens, 67-92 mm SL, Jakarta, Indonesia; YCM-HLP 224 (5), 637 (2), 7 specimens, 68-93 mm SL, Maiwara, Madang, Papua New Guinea; YCM-HLP 434 (2), 77-78 mm SL, Cebu, Philippines; YCM-HLP 650 (2), 802, 803 (12), 15 specimens, 52-68 mm SL, Sandakan, Sabah, Borneo, Malaysia; YCM-HLP 804, $42 \mathrm{~mm}$ SL, Moreton Bay, Brisbane, Queensland.

Diagnosis. A species belonging to the Leiognathus splendens complex as defined by the following characters: cheek naked; anterior dorsolateral body surface almost entirely scaled with a semicircular naked area on nape (Fig. 2A); lower margin of inner preopercular ridge smooth; interspace of pelvic keels naked (Fig. 3A); second spines of dorsal and anal fins weak (width of second spines of dorsal and anal fins $0.72-1.1 \%$ SL and $0.60-0.95 \%$ SL, respectively; Fig. 5); a dark blotch on spinous dorsal fin rather pale, grayish (Fig. 4A).

Description. Counts and measurements of the type specimens after James (1971) and non-type materials are shown in Table 1. Characters given in description of the complex and the specific diagnosis are not repeated. Body rhomboidal, dorsal profile more strongly convex than ventral one; supraorbital ridge smooth or weakly rugged with series of minute spines; ventral surface of breast naked (Fig. 3A). Maximum recorded length $139 \mathrm{~mm}$ SL (URM-P 9277, from Phuket, Thailand).

Color of fresh specimens. - Head and body almost uniformly silvery-white; tip of snout dark; lateral line scales prominent yellow but easily fade out; distal half of fin membranes between second and fifth spines of dorsal fin with a somewhat pale black blotch; fin membrane between second and third spines of anal fin white or pale yellow; spines and margin of soft portion of anal fin yellowish; posterior margin of caudal fin dark; pectoral axil dark; pectoral fin proximally with narrow dark band; pelvic fin pearl-white.

Color of preserved specimens.-Head and body almost uniformly light brown; tip of snout dark; ca. 20 wavy dark vertical lines dorsolaterally on body; distal half of fin membranes between second and fifth spines of dorsal fin with a pale black blotch; dorsal surfaces of middle pterygiophores of dorsal fin black; pectoral axil dark; pectoral fin proximally with narrow dark band.

Distribution. Leiognathus jonesi is known from Mauritius, India [Calicut, Palk Bay (type locality), and Chennai], Myanmar (Mergui), Thailand (Ranong, Phuket, Sonkgkhla, Hat Yai, Bangsapnoi, Bang Phe, Pran Buri, Hua Hin, Pattaya, and Layong), Vietnam (mouth of Mekong River, Nha Trang, Haiphong, and Long Chau Bay), China [Hainan I. (Sanya)], Philippines [Panay (Iloilo) and Cebu], Malaysia [Penang, Sabah (Kota Kinabalu and Sandakan), and off Sarawaku], Singapore (Berih), Indonesia [Jawa (Jakarta), Lombok, Sulawesi (Makassar), and Ambon], Papua New Guinea (Madan), and Australia [Queensland (Brisbane)] (Fig. 7).

Remarks. Leiognathus jonesi was established by James (1971) based on the holotype (95 mm SL) and 49 paratypes (35-92.5 mm SL) collected from Palk Bay, Tamil Nadu, southeastern India. According to the original description, all type specimens were deposited in "Central Marine Fisheries Research Institute, Mandapam Regional Centre"; however, registration numbers were not assigned. We inquired 
Table 1. Counts and measurements of Leiognathus jonesi

\begin{tabular}{|c|c|c|}
\hline & Holotype and paratypes ${ }^{a}$ & Other specimens \\
\hline Standard length (mm) & $35-95$ & 33-139 $(78.8,99)$ \\
\hline \multicolumn{3}{|l|}{ Counts } \\
\hline Dorsal fin rays & VIII, 16 & VIII, 16 (99) \\
\hline Anal fin rays & III, 14 & III, $14-15(14.0,99)$ \\
\hline Pectoral fin rays & No data & 16-19 $(18.0,99)$ \\
\hline Lateral line scales & $40-53$ & $50-61(54.3,99)$ \\
\hline Scales above lateral line & $11-13$ & 9-14 $(11.6,71)$ \\
\hline Scales below lateral line & $22-26$ & $22-28(24.8,71)$ \\
\hline Gill rakers on upper arch & $5-7$ & 5-7 $(5.8,99)$ \\
\hline Gill rakers on lower arch & $21-24$ & $19-24(20.9,99)$ \\
\hline \multicolumn{3}{|l|}{ Measurements } \\
\hline \multicolumn{3}{|l|}{ As $\%$ of standard length } \\
\hline Head length & $25-34$ & $29-34(31.4,98)$ \\
\hline Predorsal length & No data & $46-51(48.5,99)$ \\
\hline Length of dorsal fin base & No data & $54-60(57.7,99)$ \\
\hline Length of anal fin base & No data & $44-51(46.4,99)$ \\
\hline Snout to pectoral fin insertion & No data & $51-59(54.7,99)$ \\
\hline Snout to pelvic fin insertion & No data & $30-35(32.5,99)$ \\
\hline Snout to anal fin origin & No data & $35-41(37.9,99)$ \\
\hline Pectoral fin insertion to pelvic fin insertion & No data & $23-26(24.5,99)$ \\
\hline Pelvic fin insertion to anal fin origin & No data & $14-21(17.8,96)$ \\
\hline Caudal peduncle length & No data & $9.1-14(11.3,99)$ \\
\hline Body depth & $51-56$ & $51-58(54.5,99)$ \\
\hline Caudal peduncle depth & No data & $6.6-8.7(7.59,99)$ \\
\hline \multicolumn{3}{|l|}{ As \% of head length } \\
\hline Snout length & No data & $26-36(31.6,98)$ \\
\hline Eye diameter & $33-44$ & $30-40(34.8,98)$ \\
\hline Upper jaw length & No data & $32-44(36.1,98)$ \\
\hline Interorbital width & No data & $22-32(26.2,98)$ \\
\hline Length of 1st dorsal fin spine & No data & $8.1-14(10.9,88)$ \\
\hline Length of 2nd dorsal fin spine & No data & $65-80(71.9,31)$ \\
\hline Length of 3rd dorsal fin spine & No data & $56-71(65.1,15)$ \\
\hline Length of 1st anal fin spine & No data & $7.5-16(12.0,94)$ \\
\hline Length of 2 nd anal fin spine & No data & $50-68(59.7,53)$ \\
\hline Length of 3rd anal fin spine & No data & $39-59(49.5,46)$ \\
\hline Length of pectoral fin & No data & $74-91(83.5,83)$ \\
\hline Length of pelvic fin spine & No data & $30-39(34.9,87)$ \\
\hline
\end{tabular}

Figures in parentheses indicate mean values and sample size

${ }^{a}$ Data from James (1971)

Fig. 7. Distributional records of Leiognathus jonesi (circles), L. kupanensis sp. nov. (star), L. rapsoni (triangles), and L. splendens (squares)

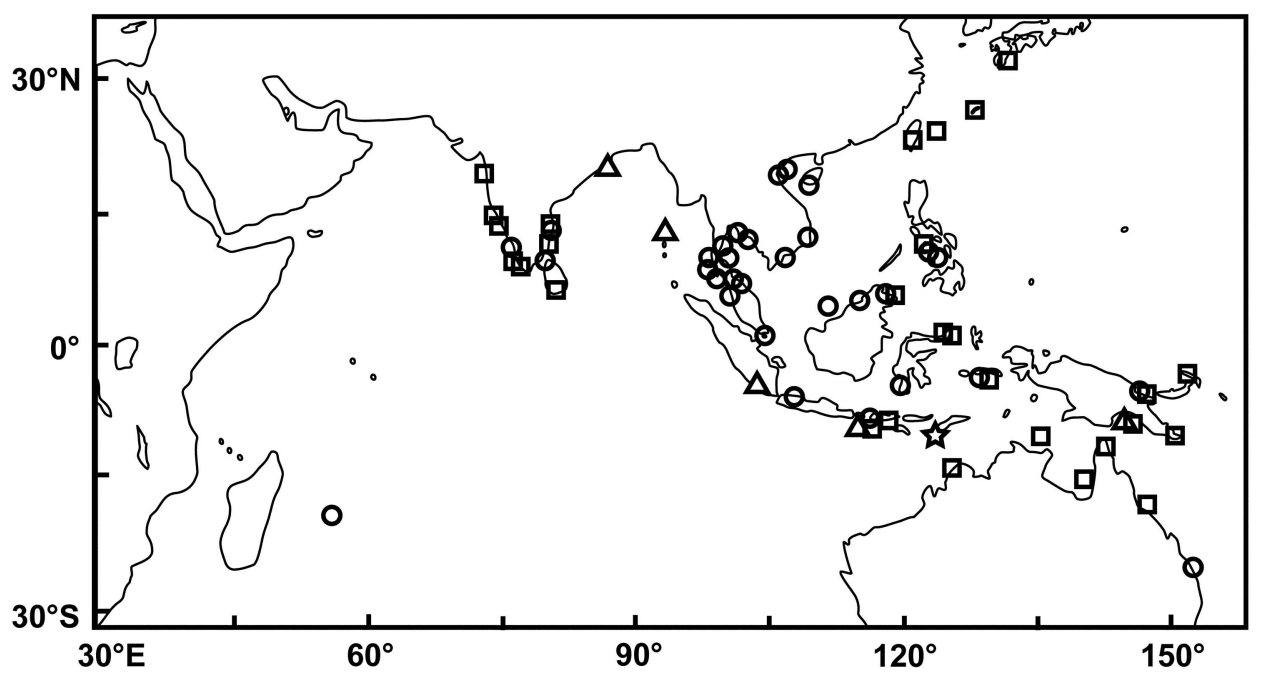




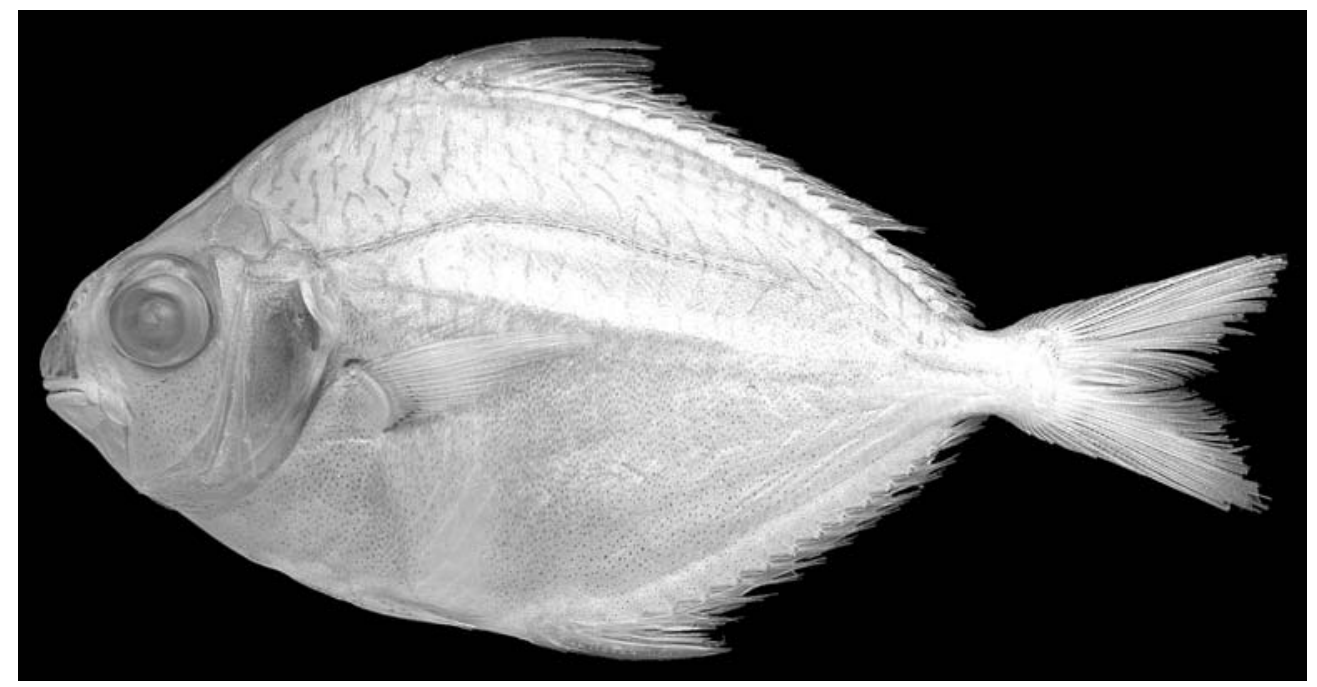

Fig. 8. Holotype of Leiognathus kupanensis, NSMT-P 69427, 80 mm SL, from Kupang, Timor, Indonesia

several times whether the types exist and are available for examination, but no reply was received. Accordingly, we asked Rohan Pethiyagoda, Wildlife Heritage Trust of Sri Lanka, to investigate the existence of the types at the "Mandapam Regional Centre" during his field research in Tamil Nadu. In early November 2003, he visited the "Mandapam Regional Centre" and tried to locate the types. However, his attempt resulted in failure; the specimens deposited there were in much confusion, no labels were in or on the specimen bottles, and there were no curatorial staff. He concluded that it would not be possible to locate and examine specific specimens. Therefore, identification of this species must be based on the original description and drawing.

According to the original description, the diagnostic characters of the species in comparison with L. splendens were as follows: a dark blotch on spinous dorsal fin gray (vs. jet black in L. splendens), spines of dorsal and anal fins weak (vs. strong), first dorsal fin spine large (second spine/first spine 4.6-7.0 vs. 3.3-8.0), and first anal fin spine large (second spine/first spine 3.1-6.0 vs. 2.5-4.5) (however, the descriptions of first spines of dorsal and anal fins are probably erroneous; the spines are somewhat smaller than those of $L$. splendens based on his data). Subsequently, Jones (1985) treated $L$. jonesi as a junior synonym of $L$. splendens, basing this decision on the density of a dark blotch on the dorsal fin, the lesser objectiveness of strengths of fin spines, and the wide overlap of proportions of first and second spines of the dorsal and anal fins. However, the specimens of $L$. jonesi examined here clearly have a more pale dark blotch on the spinous dorsal fin (Fig. 4A) and narrower second spines of dorsal and anal fins than specimens of L. splendens (Fig. 5). Additionally, L. jonesi has a small semicircular naked area on nape that is not present in L. splendens (Fig. 2). Therefore, we recognize $L$. jonesi here as a valid species. The first spines of dorsal and anal fins are relatively shorter than those of L. splendens in mean values, but the ranges widely overlap (Table 1; see also Table 4).
The fish described as "L. splendens" from Hainan I., southern China, by Zheng (1962: fig. 368) can be identified as $L$. jonesi on the basis of its somewhat paler dark marking on the dorsal fin.

Comparisons. Leiognathus jonesi is easily distinguished from L. splendens in having a paler dark blotch on dorsal fin (vs. jet black blotch in the latter; Fig. 4), prominent yellow lateral line scales if fresh (vs. dull pale to dark yellow), a semicircular naked area on nape (vs. anterior dorsolateral surface almost entirely scaled with no semicircular naked area on nape; see Fig. 2), and weak dorsal and anal fin spines (width of second spines of dorsal and anal fins $0.72-1.1 \%$ of SL and $0.60-0.95 \%$ of SL, respecitvely vs. $0.87-1.6 \%$ of SL and $0.76-1.7 \%$ of SL, respectively; Fig. 5), and is distinguished from $L$. rapsoni in lacking scales on cheek and interspace of pelvic keels (vs. scales present on cheek and interspace of pelvic keels in the latter; Figs. 2, 3). Leiognathus jonesi most closely resembles L. kupanensis sp. nov. in general body appearance and counts. However, it is distinguishable from the latter in having an almost entirely scaled anterior dorsolateral body surface with a semicircular naked area on nape (vs. widely naked anterior dorsolateral body surface; Fig. 2).

\section{Leiognathus kupanensis Kimura and Peristiwady, sp. nov. \\ (New English name: Kupang pony fish)} (Fig. 8, Table 2)

Holotype. NSMT-P 69427, 80 mm SL, Kupang, Timor, Indonesia, 18 Oct. 1999, collected by T. Peristiwady.

Paratypes. 10 specimens, 41-59 mm SL. AMS I.43380-001, $58 \mathrm{~mm}$ SL, same data as the holotype; BMNH 2004.10.26.1, $55 \mathrm{~mm}$ SL, same data as the holotype; CAS 220612, $54 \mathrm{~mm}$ SL, Kupang, Timor, Indonesia, 6 Jan. 2002, collected by T. Peristiwady; FRLM 30464, 30469, 2 specimens, 41-59 mm SL, same data as the holotype; FRLM 30470, 30473, 2 specimens, $45-52 \mathrm{~mm}$ SL, same data as CAS 220612; MNHN 2004-1856, $51 \mathrm{~mm}$ SL, same data as CAS 220612; UMMZ 243701, $57 \mathrm{~mm}$ 
Table 2. Counts and measurements of Leiognathus kupanensis sp. nov.

\begin{tabular}{|c|c|c|}
\hline & $\begin{array}{l}\text { Holotype } \\
\text { NSMT-P } 69427\end{array}$ & Paratypes \\
\hline Standard length (mm) & 80 & $41-59(52.7,10)$ \\
\hline \multicolumn{3}{|l|}{ Counts } \\
\hline Dorsal fin rays & VIII, 16 & VIII, 16 (10) \\
\hline Anal fin rays & III, 14 & III, $14(10)$ \\
\hline Pectoral fin rays & 18 & $17-18(17.8,10)$ \\
\hline Lateral line scales & 56 & $52-56(54.0,9)$ \\
\hline Scales below lateral line & 25 & $22-26(23.6,8)$ \\
\hline Gill rakers on upper arch & 5 & $5-6(5.7,9)$ \\
\hline Gill rakers on lower arch & 22 & $22-26(23.9,9)$ \\
\hline \multicolumn{3}{|l|}{ Measurement } \\
\hline \multicolumn{3}{|l|}{ As $\%$ of standard length } \\
\hline Head length & 31 & $30-33(31.5,10)$ \\
\hline Predorsal length & 50 & $48-51(48.8,10)$ \\
\hline Length of dorsal fin base & 58 & $55-59(57.2,10)$ \\
\hline Length of anal fin base & 48 & $45-49(47.1,10)$ \\
\hline Snout to pectoral fin insertion & 56 & $54-57(55.0,10)$ \\
\hline Snout to pelvic fin insertion & 32 & $32-35(33.6,10)$ \\
\hline Snout to anal fin origin & 39 & $38-42(39.9,10)$ \\
\hline Pectoral fin insertion to pelvic fin insertion & 25 & $23-26(24.6,10)$ \\
\hline Pelvic fin insertion to anal fin origin & 18 & $16-19(17.1,10)$ \\
\hline Caudal peduncle length & 10 & $8.5-13(11.0,10)$ \\
\hline Body depth & 55 & $52-57(54.8,10)$ \\
\hline Caudal peduncle depth & 7.5 & $6.3-7.5(6.76,10)$ \\
\hline \multicolumn{3}{|l|}{ As \% of head length } \\
\hline Snout length & 33 & $29-33(30.6,10)$ \\
\hline Eye diameter & 35 & $33-40(37.2,10)$ \\
\hline Upper jaw length & 35 & $31-41(36.1,10)$ \\
\hline Interorbital width & 35 & $27-36(32.8,10)$ \\
\hline Length of 1 st dorsal fin spine & 9.8 & $9.2-16(11.1,10)$ \\
\hline Length of 2 nd dorsal fin spine & 70 & $62-74(68.9,8)$ \\
\hline Length of 3rd dorsal fin spine & 62 & $53-65(59.8,5)$ \\
\hline Length of 1 st anal fin spine & 14 & $13-19(16.0,10)$ \\
\hline Length of 2 nd anal fin spine & 65 & $50-64(58.0,9)$ \\
\hline Length of 3rd anal fin spine & 53 & $48-53(49.7,6)$ \\
\hline Length of pectoral fin & 83 & $79-89(84.7,10)$ \\
\hline Length of pelvic fin spine & 38 & $31-39(34.3,10)$ \\
\hline
\end{tabular}

Figures in parentheses indicate mean values and sample size

SL, same data as the holotype; USNM 380182, $54 \mathrm{~mm} \mathrm{SL}$, same data as the holotype.

Diagnosis. A species belonging to the Leiognathus splendens complex as defined by the following characters: cheek naked (Fig. 2B); anterior dorsolateral body surface widely naked (Fig. 2B); lower margin of inner preopercular ridge smooth; interspace of pelvic keels naked (Fig. 3B); second spines of dorsal and anal fins weak (widths of dorsal and anal spines $0.72-1.2 \%$ SL and $0.60-0.91 \%$ SL, respectively; Fig. 5); dark blotch on dorsal fin rather pale, grayish (Fig. 4B).

Description. Counts and measurements of the holotype and paratypes are shown in Table 2. Characters given in description of the complex and the specific diagnosis are not repeated. Body rhomboidal, dorsal profile similar to or more strongly convex (including the holotype) than ventral one; supraorbital ridge weakly rugged with series of minute spines; ventral surface of breast naked (Fig. 3B). Maximum recorded length $80 \mathrm{~mm}$ SL (holotype).

Color of preserved specimens.-Head and body almost uniformly light brown; tip of snout dark; ca. 20 wavy dark vertical lines dorsolaterally on body; distal half of fin membranes between second and fifth spines of dorsal fin with a pale black blotch; dorsal surfaces of middle pterygiophores of dorsal fin black; pectoral axil dark; pectoral fin proximally with narrow dark band.

Distribution. Leiognathus kupanensis sp. nov. is known only from the area of Kupang, Timor, Indonesia (Fig. 7). 

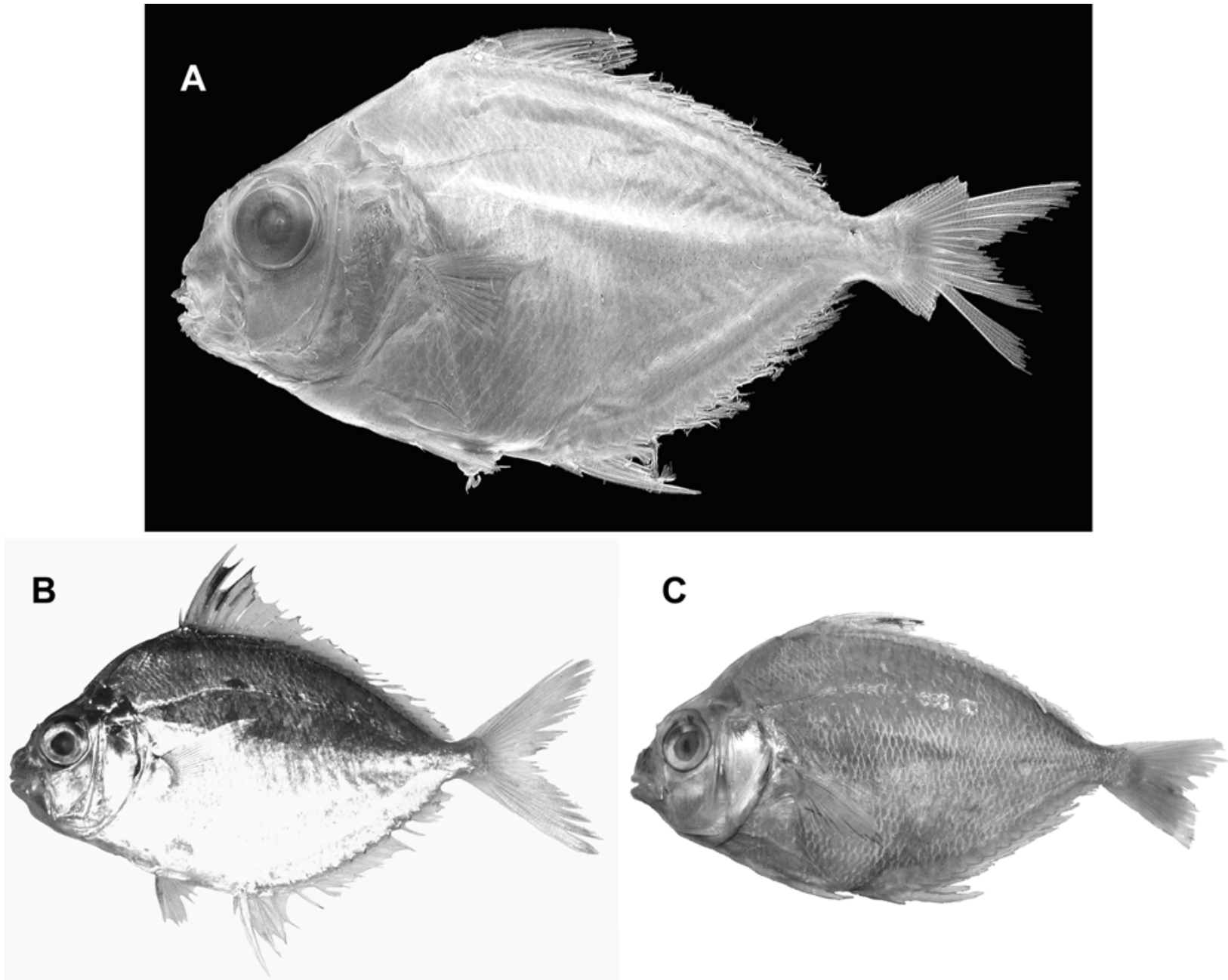

Fig. 9. Leiognathus rapsoni. A Holotype, CSIRO A 2137, $68 \mathrm{~mm} \mathrm{SL}$, from Papua New Guinea. B Non-type material, FRLM $15669,79 \mathrm{~mm}$ SL, from Lombok, Indonesia. C Holotype of Leiognathus indicus, $84 \mathrm{~mm} \mathrm{SL}$, from Puri, Orissa, India

Etymology. The specific name "kupanensis" derived from the name of the type locality of the species.

Comparisons. Leiognathus kupanensis sp. nov. is easily distinguished from the other species of the L. splendens complex in having a widely naked anterior dorsolateral body surface (vs. almost entirely scaled in the latter; Fig. 2).

\section{Leiognathus rapsoni Munro, 1964}

(English name: Papuan pony fish) (Fig. 9, Table 3)

Leiognathus rapsoni Munro, 1964: 170-171 (type locality: Redscar Bay, Gulf of Papua, Papua New Guinea); Gloerfelt-Tarp and Kailola, 1984: 171 (off Bali, Indonesia); Kimura and Peristiwady, 2000: 225 (Lombok, Indonesia); Woodland et al., 2001: 2814 (Papua New Guniea).

Leiognathus indicus Singh and Talwar, 1978: 275-277 (Puri, Orissa, India).

Holotype. CSIRO A 2137, $68 \mathrm{~mm}$ SL, off Redscar Bay, Gulf of Papua, Papua New Guinea, 26 Mar. 1955.
Paratypes. CSIRO A 3087-3089, 3 specimens, 63-68 mm SL, same data as holotype.

Non-type materials. 10 specimens, $64-84 \mathrm{~mm}$ SL. CAS SU 8026, $65 \mathrm{~mm}$ SL, Sumatra, Indonesia; FRLM 14647, 15669, 15720, 16694, 16699, 5 specimens, 64-84 mm SL, Kuta, Lombok, Indonesia; FRLM 16999, 74 mm SL, Tanjung Luar, Lombok, Indonesia; UMMZ 243702 (2), 65-81 mm SL, Kuta, Lombok, Indonesia; ZSIF 7363/2 (holotype of L. indicus), $84 \mathrm{~mm}$ SL, Puri, Orissa, India, 21 Jan. 1977.

Diagnosis. A species belonging to the Leiognathus splendens complex as defined by the following characters: cheek scaled (Fig. 2C); anterior dorsolateral body surface almost completely scaled (Fig. 2C); lower margin of inner preopercular ridge serrated; interspace of pelvic keels scaled (Fig. 3C, D); dark blotch on dorsal fin rather pale, grayish (Fig. 4C).

Description. Counts and measurements of the holotype, paratypes, and other specimens are shown in Table 3. Characters given in description of the complex and the specific diagnosis are not repeated. Body ovoid, dorsal and ventral profiles of body similarly convex; supraorbital ridge rugged with series of many minute granules; ventral surface of breast 
Table 3. Counts and measurements of Leiognathus rapsoni

\begin{tabular}{|c|c|c|c|c|}
\hline & $\begin{array}{l}\text { Holotype } \\
\text { CSIRO A } 2137\end{array}$ & $\begin{array}{l}\text { Paratypes } \\
\text { CSIRO A 3087- } \\
3089\end{array}$ & $\begin{array}{l}\text { Holotype of } \\
\text { L. indicus } \\
\text { ZSI F7363/2 }\end{array}$ & Other specimens \\
\hline Standard length (mm) & 68 & $63-68(65.1,3)$ & 88 & $64-84(72.3,9)$ \\
\hline \multicolumn{5}{|l|}{ Counts } \\
\hline Dorsal fin rays & VIII, 16 & VIII, 16 (3) & VIII, 16 & VIII, 16 (9) \\
\hline Anal fin rays & III, 14 & III, $14(3)$ & III, 14 & III, 14 (9) \\
\hline Pectoral fin rays & 17 & $17-18(17.7,3)$ & 17 & $17(9)$ \\
\hline Lateral line scales & 51 & $49-53(51.0,3)$ & 52 & $46-51(47.9,9)$ \\
\hline Scales above lateral line & 10 & $8-10(9.0,3)$ & 10 & $8-9(8.4,9)$ \\
\hline Scales below lateral line & 18 & $18-19(18.3,3)$ & 20 & $18-21(19.3,9)$ \\
\hline Gill rakers on upper arch & 5 & $4-6(5.0,3)$ & 4 & $5-6(5.4,9)$ \\
\hline Gill rakers on lower arch & 19 & $21-22(21.3,3)$ & 22 & $18-20(19.1,9)$ \\
\hline \multicolumn{5}{|l|}{ Measurements } \\
\hline \multicolumn{5}{|l|}{ As $\%$ of standard length } \\
\hline Head length & 33 & $31-32(31.7,3)$ & 33 & $29-32(30.8,9)$ \\
\hline Predorsal length & 49 & $45-47(45.7,3)$ & No data & $44-49(46.7,9)$ \\
\hline Length of dorsal fin base & 57 & $55-57(56.3,3)$ & No data & $57-61(58.8,9)$ \\
\hline Length of anal fin base & 47 & $45-48(46.8,3)$ & No data & $47-50(48.6,9)$ \\
\hline Snout to pectoral fin insertion & 58 & $56-57(56.3,3)$ & No data & $53-57(54.6,9)$ \\
\hline Snout to pelvic fin insertion & 33 & $35-36(35.7,3)$ & No data & $30-34(32.2,9)$ \\
\hline Snout to anal fin origin & 39 & $42-43(42.7,3)$ & No data & $36-43(39.0,8)$ \\
\hline Pectoral fin insertion to pelvic fin insertion & 23 & $22-31(26.0,3)$ & No data & $24-25(24.6,8)$ \\
\hline Pelvic fin insertion to anal fin origin & 18 & $14-16(15.3,3)$ & No data & $15-19(16.9,8)$ \\
\hline Caudal peduncle length & 10 & $11-12(11.3,3)$ & No data & $9.4-11(10.1,9)$ \\
\hline Body depth & 52 & $50-52(51.0,3)$ & 54 & $53-57(24.7,9)$ \\
\hline Caudal peduncle depth & 7.6 & $5.7-6.6(6.23,3)$ & No data & $6.8-8.3(7.60,9)$ \\
\hline \multicolumn{5}{|l|}{ As $\%$ of head length } \\
\hline Snout length & 28 & $26-30(28.0,3)$ & 30 & $29-35(31.4,9)$ \\
\hline Eye diameter & 36 & $34-39(37.0,3)$ & No data & $33-36(34.6,9)$ \\
\hline Upper jaw length & Damaged & $31(1)$ & No data & $29-37(33.6,8)$ \\
\hline Interorbital width & 28 & $32-37(34.0,3)$ & No data & $24-28(26.8,9)$ \\
\hline Length of 1st dorsal fin spine & 12 & $12-13(12.3,3)$ & No data & $10-16(12.8,8)$ \\
\hline Length of 2 nd dorsal fin spine & 68 & $59-69(60.7,3)$ & No data & $68-74(70.5,6)$ \\
\hline Length of 3rd dorsal fin spine & 53 & $48(2)$ & No data & $56-63(59.5,2)$ \\
\hline Length of 1 st anal fin spine & 12 & $16-18(17.0,3)$ & No data & $13-19(15.9,8)$ \\
\hline Length of 2 nd anal fin spine & 58 & $56-62(58.0,3)$ & 61 & $62-65(63.6,5)$ \\
\hline Length of 3rd anal fin spine & Damaged & $36(1)$ & No data & $52-58(54.8,4)$ \\
\hline Length of pectoral fin & 74 & $74(1)$ & No data & $70-79(74.7,9)$ \\
\hline Length of pelvic fin spine & Damaged & $33-38(36.0,3)$ & No data & $37-43(40.1,7)$ \\
\hline
\end{tabular}

Figures in parentheses indicate mean values and sample size

completely scaled (holotype) or very narrow naked area anteriorly (Fig. 3C,D). Maximum recorded length $84 \mathrm{~mm} \mathrm{SL}$ [FRLM 14647 from Lombok, Indonesia, and ZSIF 7363/2 (holotype of Leiognathus indicus) from Puri, Orissa, India].

Color of fresh specimens.-Head and body almost uniformly silvery-white, somewhat bluish dorsally; tip of snout dark; lateral line scales yellowish; dorsal fin membrane between second and fifth spines with a somewhat pale black blotch; anal fin membrane between second and third spines, caudal fin, and pectoral fin proximally yellow; dorsal, anal, and caudal fin margins dark; pectoral axil blackish.

Color of preserved specimens.-Head and body almost uniformly light brown; tip of snout dark; ca. 20 wavy dark vertical lines dorsolaterally on body; dorsal fin membrane between second and fifth spines with a pale black blotch; dorsal surfaces of middle pterygiophores of dorsal fin black; pectoral axil dark; pectoral fin proximally with narrow dark band.

Distribution. Leiognathus rapsoni is known only from India [Puri, Orissa (type locality of $L$. indicus) and North Andaman I.], Indonesia (Sumatra and Lombok), and Papua New Guinea [Gulf of Papua (type locality)] (Fig. 7).

Remarks: Munro (1964) established Leiognathus rapsoni based on the holotype (CSIRO A 2137; Fig. 9A) and three paratypes (CSIRO A 3087-3089) from Red Scar Bay, Gulf of Papua, Papua New Guinea. He stated in the original description that L. rapsoni differs from the closest species, L. splendens, in having scales on cheek, shallower body (SL/ body depth $=1.9-2.1$ vs. $1.75-1.8$ in L. splendens), fewer lateral line scale count (51-55 vs. 55-60), and more numer- 
ous dark streaks dorsolaterally on body (20 vs. 12). From our observation and measurements, the scaled cheek is the best diagnostic character of the species, whereas proportion of body depth $(50-57 \%$ SL vs. $42-60 \%$ in $L$. splendens) and number of dark streaks on body (ca. 20 in both species) are unusable for discriminating between the two species. Although L. rapsoni has a somewhat lower scale count than the other species belonging to the $L$. splendens complex, the ranges overlap (46-53 in the former vs. 50-66 in the latter).

Leiognathus indicus was described by Singh and Talwer (1978) based on the holotype (ZSI 7363/2; Fig. 9C) and eight paratypes [ZSI 7364/2 (7 specimens) and 7365/2 (1 specimen)] from Puri, Orissa and North Andaman I., India as a new Leiognathus species characterized by possession of cheek scales, deep body, and conspicuous black blotch on spinous dorsal fin. Comparing the original description of $L$. rapsoni, they stated that $L$. indicus differed from the latter species in having fewer gill rakers (18-19 vs. $21-23$ in the latter) and a short second spine of anal fin (2.1-2.5 in body depth vs. 2.7-2.9). However, the gill raker counts of the holotype of $L$. indicus and the type series of $L$. rapsoni in the original descriptions $(4+18$ and $3-5+21-23$, respectively) are erroneous; the correct counts are $4+22$ and 4-6 + 19-22 (Table 3). Furthermore, the proportion of second spine of anal fin in the holotype of L. indicus (2.6 in body depth) agrees with that in the type series of L. rapsoni (2.62.9). Therefore, we conclude that $L$. indicus is a junior synonym of L. rapsoni.

Comparisons. Leiognathus rapsoni is easily distinguished from the other species of the L. splendens complex in having scales on cheek and interspace between pelvic keels (vs. cheek and interspace between pelvic keels completely naked; Figs. 2, 3).

\section{Leiognathus splendens (Curvier, 1829) \\ (English name: Splendid pony fish) \\ (Japanese name: Taiwan-hiiragi) \\ (Figs. 10, 11, Table 4)}

Equula splendens Cuvier 1829: 212 (type locality: Chennai, India); Day, 1876: 239-240, pl. 55, fig. 3 (? in part, Red Sea, sea of India to the Malay Archipelago).

Equula gomorah Valenciennes in Cuvier and Valenciennes, 1835: 80-82 (type locality: Pondicherry, India).

Equula ovalis De Vis, 1884: 543 (type locality: Cape York, Queensland, Australia).

Equula simplex De Vis, 1884: 544 (type locality: Cape York, Queensland, Australia).

Leiognathus spilotus Fowler, 1904: 516-517 (type locality: Padang, Sumatra, Indonesia).

Leiognathus philippinus Fowler, 1918: 15-17 (type locality: Philippines).

Leiognathus splendens Weber and de Beaufort, 1931: 324-326 [in part, Sea of Penang, Singapore, Banka, Sumatra, Java, Madura, Bawean, Bali, Lombok, Sumbawa, Borneo (Kalimantan), Sulawesi, Batjan, Ternate, Ambon, Buru, Seram, Obi major, Aru Is., Timor, Red Sea, Madagascar, Mauritius, British India, Sri Lanka, Andamans, Thailand, China (Including Taiwan), Philippines, Queensland, Fiji Is.];
Kühlmorgen-Hille, 1974: LEIOG Leiog 10 (in part, Eastern Indian Ocean and Western Central Pacific); James, 1978: 148-149 [? in part, India (Gulf of Mannar, Arabian Sea, Bay of Bengal]; Uyeno and Yabumoto, 1984: 159 (Okinawa, Japan); Gloerfelt-Tarp and Kailola, 1984:171 (off Bali); James, 1984: LEIOG Leiog 10 (? in part, Mauritius, Madagascar, Red Sea, India, Sri Lanka, eastern Indian Ocean, Western Central Pacific); Jones, 1985: (northern Australia); Shen and Lin, 1985: 125-138 (Taiwan); Shen, 1993: 345 (Taiwan); Kimura and Peristiwady, 2000: 227 (Lombok, Indonesia); Woodland et al., 2001: 2815 (in part, Mauritius, Madagascar, Red Sea, India to island of western Central Pacific as far as Fiji, north to Okinawa, south to northern part of Australia); Senou, 2002: 811 (Ryukyu Is, Japan, IndoWest Pacific); Kimura et al., 2003b: 84 (Bitung, Sulawesi, Indonesia). Leiognathus daura (not of Cuvier); Mohsin and Ambak, 1996: 346, fig. 251 (Malaysia).

\section{Neotype. RMNH 1441, 98 mm SL, Chennai, India.}

Non-type materials. 164 specimens, 25-125 mm SL. AMS I. 15557126, $90 \mathrm{~mm}$ SL, Gulf of Carpentaria, Australia; AMS I. 20402-045 (3), 58-80 mm SL, Bonaparte Archipelago, Western Australia; AMS I. 20826-019 (5), 80-97 mm SL, Palm I., Queensland, Australia, AMS I. 21841-004 (6), 78-84 mm SL, Arafura Sea, Australia; AMS IA. 4900, $30 \mathrm{~mm}$ SL, Bonaparte Archipelago, Western Australia (paralectotype of E. ovalis); ANSP 27529, $25 \mathrm{~mm}$ SL, Padang, Sumatra, Indonesia, date unknown (holotype of L. spilotus); ANSP 47486, $53 \mathrm{~mm}$ SL, Philippines, Nov. 1917 (holotype of L. philippinus);ANSP 47487-47490, 4 specimens, 49-53 mm SL, Philippines, Nov. 1917 (paratypes of L. philippinus); ASIZP 57566 (4), 57611 (7), 11 specimens, 44-584 mm SL, Tzengwen River, Taiwan; ASIZP 57614, 70 mm SL, Shuanghsi River, Taiwan; ASIZP 57685 (2), 60-83 mm SL, Erhjen River, Taiwan; ASIZP 57689, 43 mm SL, Tungshiao, Taiwan; ASIZP 58819, 86 mm SL, Nanliao, Taiwan; BMNH 1889.2.1.3262, $78 \mathrm{~mm}$ SL, Chennai, India; CAS SU 30512, $86 \mathrm{~mm}$ SL, Vizagapatam, Chennai, India, CAS SU 41642 (3), 40-48 mm SL, Kerala, India; CSIRO A 41, A 43, 2 specimens, 58-77 mm SL, Salamaua, Morobe, Papua New Guinea; CSIRO A 2176-2179, A 2348, A 2349, A 3995, A 3996, C 3424, C 3425, CA2690, H 3610 (4), 15 specimens, 73$10 \mathrm{~mm}$ SL, Gulf of Carpentaria, Australia; CSIRO A 3034, $54 \mathrm{~mm}$ SL, Kerema Bay, Gulf of Papua, Papua New Guinea; CSIRO B 2215 (7), 83$112 \mathrm{~mm}$ SL, Arafura Sea, Australia; CSIRO C 1784, 84 mm SL, Manus Island, Bismarck Archipelago, Papua New Guinea; FRLM 14788, 14789, 16997, 16998, 17000, 20047, 20385, 7 specimens, 60-91 mm SL, Tanjung Luar, Lombok, Indonesia; FRLM 15724, 16695, 17267, 17268, 20248, 5 specimens, 38-71 mm SL, Kuta, Lombok, Indonesia; FRLM 17126, 17272, 2 specimens, 40-45 mm SL, Gerupuk, Lombok, Indonesia; FRLM 21492, 21497, 21501, 23514, 23775, 5 specimens, 55-98 mm SL, Passo, Ambon, Indonesia; FRLM 21518, 65 mm SL, Guru Guru, Ambon, Indonesia; FRLM 25568-25570, 25795-25797, 26464, 26465, 8 specimens, 61$90 \mathrm{~mm}$ SL, Pintukota, Lembeh I., North Sulawesi, Indonesia; FRLM 30790, 92 mm SL, Iloilo, Panay I., Philippine; MNHN A-6724, 50 mm SL, Pondicherry, India, date unknown (lectotype of E. gomorah); MNHN A-6726, $89 \mathrm{~mm}$ SL, Malabar, India, date unknown (paralectotype of E. gomorah); MNHN A-6727 (2), 94-100mm SL, Ambon, Indonesia; MUFS 9346, 82 mm SL, Iloilo, Panay I., Philippines; MUFS 12909, 125 mm SL, Meitsu, Nango, Miyazaki, Japan; MUFS 13095-13098, 4 specimens, 73-91 mm SL, Ambon, Indonesia; MUFS 16915-16919, 17022-17024, 9 specimens, 61-79 mm SL, Mangalore, India; MUFS 16970-16973, 4 specimens, 81-84 mm SL, Malpe, India; NSMT-P 35323 (2), 70-81 mm SL, Tainan, Taiwan; QM I.1702, 35 mm SL, Cape York, Australia, date unknown (lectotype of E. simplex); QM I.1703, $34 \mathrm{~mm}$ SL, Cape York, Australia, date unknown (lectotype of E. ovalis); QM I.9810 (6 of 8), 28-34 mm SL, Cape York, Australia, date unknown (paralectotypes of E. ovalis); QM I.9811 (1 of 2), 35 mm SL, Cape York, 
Table 4. Counts and measurements of Leiognathus splendens

\begin{tabular}{|c|c|c|c|c|c|}
\hline & $\begin{array}{l}\text { Neotype } \\
\text { RMNH } \\
1441\end{array}$ & $\begin{array}{l}\text { Lectotype of } \\
\text { E. gomorah } \\
\text { MNHN } 6724\end{array}$ & $\begin{array}{l}\text { Paralectotype } \\
\text { of E. gomorah } \\
\text { MNHN } 6726\end{array}$ & $\begin{array}{l}\text { Lectotype } \\
\text { of E. ovalis } \\
\text { QM I. } 1703\end{array}$ & $\begin{array}{l}\text { Paralectotypes } \\
\text { of E. ovalis } \\
\text { AMS IA. } 4900 \text {, } \\
\text { QM I. } 9810\end{array}$ \\
\hline Standard length (mm) & 68 & 50 & 89 & 34 & $28-34(30.6,7)$ \\
\hline \multicolumn{6}{|l|}{ Counts } \\
\hline Dorsal fin rays & VIII, 16 & VIII, 16 & VIII, 16 & VIII, 16 & VIII, 16 (7) \\
\hline Anal fin rays & III, 14 & III, 14 & III, 14 & III, 14 & III, 14 (7) \\
\hline Pectoral fin rays & 17 & 18 & 17 & 18 & $17-19(17.7,3)$ \\
\hline Lateral line scales & 51 & 52 & 55 & Damaged & $56-61(57.8,6)$ \\
\hline Scales above lateral line & 10 & 13 & 14 & Damaged & $12-14(13.0,3)$ \\
\hline Scales below lateral line & 18 & 30 & 29 & Damaged & $28-30(29.0,2)$ \\
\hline Gill rakers on upper arch & 5 & 6 & 6 & 5 & $5(5)$ \\
\hline Gill rakers on lower arch & 19 & 21 & 21 & 20 & $19-22(20.4,5)$ \\
\hline \multicolumn{6}{|l|}{ Measurements } \\
\hline \multicolumn{6}{|l|}{ As $\%$ of standard length } \\
\hline Head length & 33 & 32 & 31 & 33 & $29-34(32.0,7)$ \\
\hline Predorsal length & 49 & 45 & 46 & 43 & $38-48(42.9,7)$ \\
\hline Length of dorsal fin base & 57 & 58 & 58 & 55 & $52-58(55.3,7)$ \\
\hline Length of anal fin base & 47 & 47 & 46 & 45 & $39-46(42.9,7)$ \\
\hline Snout to pectoral fin insertion & 58 & 55 & 58 & 55 & $50-59(54.4,7)$ \\
\hline Snout to pelvic fin insertion & 33 & 34 & 34 & 34 & $32-54(37.6,7)$ \\
\hline Snout to anal fin origin & 39 & 38 & 41 & 40 & $36-43(39.3,7)$ \\
\hline $\begin{array}{l}\text { Pectoral fin insertion to } \\
\text { pelvic fin insertion }\end{array}$ & 23 & 22 & 24 & 22 & $20-26(21.6,7)$ \\
\hline $\begin{array}{l}\text { Pelvic fin insertion to } \\
\text { anal fin origin }\end{array}$ & 18 & 17 & 19 & Damaged & $13-20(16.3,6)$ \\
\hline Caudal peduncle length & 10 & 11 & 11 & 13 & $9.2-12(11.0,7)$ \\
\hline Body depth & 52 & 53 & 55 & 45 & $42-48(45.6,7)$ \\
\hline Caudal peduncle depth & 7.6 & 7.4 & 7.5 & 6.7 & $5.9-7.0(6.5,7)$ \\
\hline \multicolumn{6}{|l|}{ As $\%$ of head length } \\
\hline Snout length & 28 & 29 & 28 & 25 & $20-40(27.6,7)$ \\
\hline Eye diameter & 36 & 39 & 38 & 35 & 34-44 $(39.6,7)$ \\
\hline Upper jaw length & 39 & 31 & 33 & 32 & $27-38(33.3,4)$ \\
\hline Interorbital width & 28 & 29 & 28 & 29 & $28-35(31.0,7)$ \\
\hline Length of 1st dorsal fin spine & 12 & 14 & Damaged & 12 & $12-16(13.8,4)$ \\
\hline Length of 2 nd dorsal fin spine & 68 & Damaged & Damaged & Damaged & $61-71(66.8,4)$ \\
\hline Length of 3rd dorsal fin spine & 53 & Damaged & Damaged & Damaged & $48-51(49.7,3)$ \\
\hline Length of 1 st anal fin spine & 12 & 19 & 22 & Damaged & $18-25(21.0,5)$ \\
\hline Length of 2 nd anal fin spine & 58 & 58 & Damaged & Damaged & $55-62(59.0,6)$ \\
\hline Length of 3rd anal fin spine & Damaged & 45 & Damaged & Damaged & $40(1)$ \\
\hline Length of pectoral fin & 74 & 83 & 77 & Damaged & $78(1)$ \\
\hline Length of pelvic fin spine & 45 & 39 & 43 & Damaged & $34-41(38.0,2)$ \\
\hline
\end{tabular}

Figures in parentheses indicate mean values and sample size

Australia, date unknown (paralectotype of E. simplex); UMMZ 243703 (10), 59-73 mm SL, Tigbauan, Iloilo, Panay I., Philippines; URM-P 928, 37983,37984, 3 specimens, 66-78 mm SL, Haneji-naikai, Okinawa, Japan; URM-P 6348, 117 mm SL,Zamami I., Kerama I., Okinawa,Japan;URMP 11733, 31209, 32176, 32177, 32196-32199, 34227, 9 specimens, 3952 mm SL, Iriomote I., Okinawa, Japan; URM-P 20854-20855, 2 specimens, 59-72 mm SL, Kavieng, New Ireland, Papua New Guinea; URM-P 33227, 33228, 2 specimens, 44-45 mm SL, Jilong, Taiwan; YCM-HLP 184, $68 \mathrm{~mm}$ SL, Sandakan, Sabah, Borneo, Malaysia; YCM-HLP 648 (3), 59$65 \mathrm{~mm}$ SL, Sandakan, Sabah, Borneo, Malaysia; ZRC 3771, 84 mm SL, Sabah, Borneo, Malaysia.
Materials for distributional records. 29 specimens, $27-82 \mathrm{~mm}$ SL. BMNH 1871.7.20.128, 75 mm SL, Manado, Sulawesi, Indonesia; BMNH 1884.5.15.8-9 (2), 44 mm SL, southern Taiwan; BMNH 1983.10.19.28, $52 \mathrm{~mm}$ SL, Sri Lanka; CSIRO A 124, 125, 2 specimens, 46-52 mm SL, Kapa Kapa, Papua New Guinea; CSIRO A 44, A 49, A 50, 3 specimens, 41-53 mm SL, Salamaua, Papua New Guinea; CSIRO A 182, 27 mm SL, Madang, Papua New Guinea; CSIRO A 206,34 mm SL, Oro Bay, Papua New Guinea; FRLM 30948, 30949, 2 specimens, 78-79 mm SL, Roxas, Panay, Philippines; MUFS 19416, 19419, 19421, 19423-19428, 12 specimens, 58-82 mm SL, Mangalore, India; MUFS 19521, $64 \mathrm{~mm} \mathrm{SL}$, Trivandram, India; NSMT-P 547070, 2 specimens, 60-63 mm SL, Kuta, 


\begin{tabular}{|c|c|c|c|c|c|}
\hline $\begin{array}{l}\text { Lectotype } \\
\text { of E. simplex } \\
\text { QM I. } 1702\end{array}$ & $\begin{array}{l}\text { Paralectotype } \\
\text { of E. simplex } \\
\text { QM I. } 9811\end{array}$ & $\begin{array}{l}\text { Holotype of } \\
\text { E. spilotus } \\
\text { ANSP } 27529\end{array}$ & $\begin{array}{l}\text { Holotype of } \\
\text { L. philippinus } \\
\text { ANSP } 47486\end{array}$ & $\begin{array}{l}\text { Paratypes of } \\
\text { L. philippinus } \\
\text { ANSP } 47487- \\
47490\end{array}$ & Other specimens \\
\hline 35 & 35 & 25 & 53 & $49-53(50.8,4)$ & $38-125(71.5,146)$ \\
\hline VIII, 16 & VIII, 16 & VIII, 16 & VIII, 16 & VIII, 16 (4) & $\begin{array}{l}\text { VIII-IX, 15-17 } \\
(\text { III, 16.0, 146) }\end{array}$ \\
\hline III, 14 & III, 14 & III, 14 & III, 14 & III, 14 (4) & $\begin{array}{l}\text { III, 13-15 } \\
\text { (III, 14.0, 146) }\end{array}$ \\
\hline 18 & Damaged & Damaged & 18 & $17-18(17.5,4)$ & $16-19(17.3,146)$ \\
\hline 64 & 58 & Damaged & 55 & $57-61(58.5,4)$ & $50-66(56.7,142)$ \\
\hline 13 & 12 & Damaged & 13 & $12-13(12.5,4)$ & 9-26 $(13.1,142)$ \\
\hline 29 & 28 & Damaged & 24 & $26-29(27.0,4)$ & $12-33(27.1,141)$ \\
\hline 6 & 6 & Damaged & 6 & $5-6(5.5,4)$ & $4-7(5.7,145)$ \\
\hline 20 & 19 & Damaged & 19 & $19(4)$ & $18-24(20.6,145)$ \\
\hline 34 & 32 & 30 & 32 & $31-33(32.0,4)$ & $29-35(31.9,145)$ \\
\hline 45 & 45 & 43 & 45 & $44-47(45.3,4)$ & $42-51(46.4,142)$ \\
\hline 55 & 57 & 59 & 57 & $55-58(56.0,4)$ & $53-61(57.6,146)$ \\
\hline 45 & 43 & Damaged & 45 & $44-45(44.3,4)$ & $42-50(45.3,146)$ \\
\hline 53 & 54 & Damaged & 54 & $52-54(53.0,4)$ & $50-61(55.3,146)$ \\
\hline 34 & 33 & Damaged & 34 & $32-34(33.3,4)$ & $30-36(33.1,146)$ \\
\hline 39 & 40 & Damaged & 38 & $36-37(36.5,4)$ & $34-42(37.9,146)$ \\
\hline 22 & 20 & Damaged & 21 & $21-22(21.8,4)$ & $19-26(22.6,145)$ \\
\hline Damaged & 16 & Damaged & Damaged & Damaged & $15-22(18.6,135)$ \\
\hline 13 & 12 & 10 & 11 & $12-13(12.3,4)$ & $9.0-13(10.9,146)$ \\
\hline 46 & 47 & 45 & 46 & $47-48(47.3,4)$ & $42-60(50.5,146)$ \\
\hline 7.2 & 6.7 & 7.3 & 6.3 & $6.6-7.0(6.78,4)$ & $5.8-9.3(7.28,146)$ \\
\hline 24 & 29 & & 26 & $26-29(27.5,4)$ & $24-37(28.9,145)$ \\
\hline 33 & 36 & 43 & 37 & $36-38(37.0,4)$ & $31-40(35.5,145)$ \\
\hline 35 & 32 & 34 & 35 & $33-35(33.8,4)$ & $23-38(33.9,104)$ \\
\hline 30 & 31 & Damaged & 28 & $27-29(28.0,4)$ & $25-36(28.2,145)$ \\
\hline 13 & Damaged & 12 & 12 & $12(3)$ & $7.0-15.5(14.6,140)$ \\
\hline 65 & 47 & 75 & 69 & $61-68(65.7,3)$ & $59-80(68.3,108)$ \\
\hline Damaged & & Damaged & Damaged & $62(1)$ & $44-73(58.1,77)$ \\
\hline 17 & 11 & 20 & 18 & $17-20(18.3,4)$ & $12-22(17.3,139)$ \\
\hline Damaged & 43 & Damaged & Damaged & $52-55(53.3,3)$ & $46-71(56.8,117)$ \\
\hline Damaged & Damaged & Damaged & Damaged & $44-51(47.5,2)$ & $32-57(46.9,103)$ \\
\hline 81 & Damaged & Damaged & 81 & $77-87(81.8,4)$ & $66-87(78.4,140)$ \\
\hline Damaged & 36 & Damaged & Damaged & Damaged & $32-47(38.2,129)$ \\
\hline
\end{tabular}

Lombok, Indonesia; SMF 4311, 58 mm SL, Belang I., Sumbawa, Indonesia; YCM-HLP 801, 60 mm SL, Mumbai, India.

Diagnosis. A species belonging to the Leiognathus splendens complex as defined by the following characters: cheek naked (Fig. 2D); anterior dorsolateral body surface almost completely scaled without a semicircular naked area on nape (Fig. 2D); lower margin of inner preopercular ridge smooth or weakly serrated (including the neotype); interspace of pelvic keels naked (Fig. 3E); second spines of dorsal and anal fins robust (width of second spines of dorsal and anal fins $0.87-1.6 \%$ of SL and $0.76-1.7 \%$ of SL, respectively; Fig. 5); a jet black blotch on spinous dorsal fin (Fig. 4D).

Description. Counts and measurements of the neotype and other specimens are shown in Table 4. Characters given in description of the complex and the specific diagnosis are not repeated. Body rhomboidal to somewhat oblong, dorsal profile similar to or somewhat more strongly convex (including the neotype) than ventral one; supraorbital ridge 


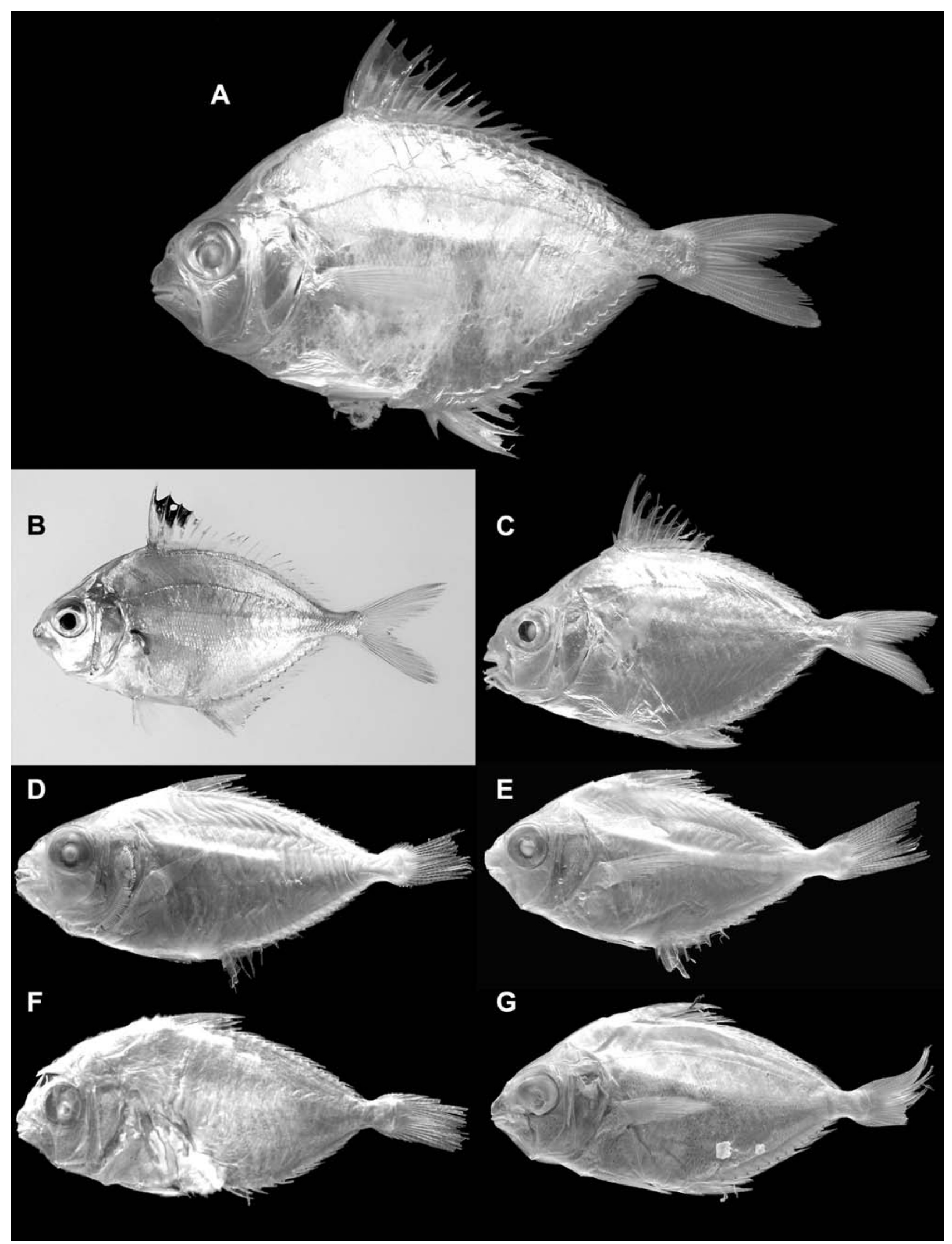

Fig. 10. Leiognathus splendens. A Neotype, RMNH 1441, $98 \mathrm{~mm} \mathrm{SL}$, from Chennai, India. B Non-type material, FRLM 20385, $60 \mathrm{~mm} \mathrm{SL,} \mathrm{from}$ Lombok, Indonesia. C Lectotype of Equula gomorah, MNHN A6724, $50 \mathrm{~mm} \mathrm{SL}$, from Pondicherry, India. D Lectotype of E. ovalis, QM I. 1703, $34 \mathrm{~mm}$ SL, from Cape York, Australia. E Lectotype of E. simplex, QM I. 1702, $35 \mathrm{~mm} \mathrm{SL}$, from Cape York, Australia. F Holotype of L. spilotus, ANSP 27529, 25 mm SL, from Padan, Sumatra, Indonesia. G Holotype of L. philippinus, ANSP 47486, 53 mm SL, from Philippines 


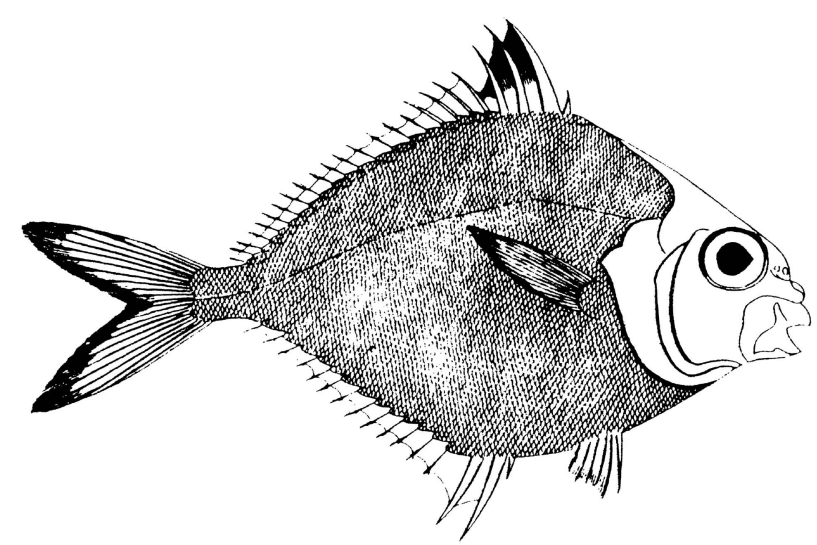

Fig. 11. A drawing of "Goomorah Karah" after Russell (1803)

smooth or weakly rugged with series of minute spines (including the neotype); ventral surface of breast naked (Fig. 3E). Maximum recorded length $125 \mathrm{~mm}$ SL (MUFS 12909, from Miyazaki, Japan).

Color of fresh specimens.-Head and body almost uniformly silvery-white; tip of snout dark; lateral line scales pale yellow; distal half of fin membranes between second and sixth spines of dorsal fin with a jet black blotch; margins of soft dorsal, soft anal, and caudal fins pale yellow, spinous anal and pectoral fins pale yellow; caudal fin and sometimes soft dorsal fin additionally fringed with pale black; pelvic fin pearl white; pectoral axil dark.

Color of preserved specimens.-Head and body almost uniformly light brown or light brown dorsally and silverywhite ventrally; tip of snout dark; wavy dark vertical lines dorsolaterally on body; distal half of fin membranes between second and fifth spines of dorsal fin with a jet black blotch; dorsal surfaces of middle pterygiophores of dorsal fin black; pectoral axil dark; pectoral fin proximally with narrow dark band.

Distribution. Leiognathus splendens is known from India [Mumbai, Malpe, Mangalore, Kerala State, Malabar, Trivandrum, Pondicherry, Chennai (type locality)], Sri Lanka, Japan (Miyazaki, Okinawa I., Iriomote I.), Taiwan, Philippines, Malaysia (Sabah), Indonesia [Sulawesi (Manado, Bitung), Lombok, Sumbawa, Ambon], Papua New Guinea (Madan, Kapa kappa, Salamaua, Gulf of Papua, Admiralty Is., Kavieng), and Australia [Palm I. (Queensland), Cape Yolk, Gulf of Carpentaria, Arafura Sea, Admiralty Gulf (Western Australia)] (Fig. 7).

Remarks. Leiognathus splendens was originally described by Cuvier (1829) as Equula splendens based on Russell's (1803) description and drawing of "Goomorah karah" from Vizagapatam, Chennai, India (Fig. 11). Russell's fish undoubtedly belongs to the L. splendens complex because of the orbit above the horizontal through the gape and presence of a black blotch on top of spinous dorsal fin. Russell (1803) stated that the fish had no scales on head, and consequently it was not L. rapsoni. However, it is impossible to identify accurately the fish as L. splendens or the sympatric species, L. jonesi, because he did not describe density of a dark blotch on spinous dorsal fin, thickness of second spines of dorsal and anal fins, or squamation on anterodorsal surface of body. On the other hand, the name "Leiognathus splendens" is the most widespread among the complex, and James (1971) regarded "L. splendens" as the species having a denser marking on dorsal fin and more robust second spines of dorsal and anal fins in comparison with L. jonesi. Therefore, we consider L. splendens to be valid and define it as the species having no cheek scales, no naked area on nape, robust dorsal and anal fin spines, and a jet black marking on dorsal fin. To clarify the taxonomic status of this species and avoid future confusion, we designate here the specimen collected from Chennai (RMNH 1441) as the neotype.

Equula gomorah was established by Valenciennes in Cuvier and Valenciennes (1835) based on four syntypes collected from Malabar Coast, Pondicherry, India, and the Red Sea. The lectotype (MNHN A 6724, 50mmSL, from Pondicherry, India; here designated; Fig. 10C) and paralectotype (MNHN A 6726, $89 \mathrm{~mm} \mathrm{SL}$, from the Malabar Coast, India) were examined here and are considered to be conspecific with L. splendens based on the jet black marking on dorsal fin, robust second spine of anal fin, fine weak serration on lower margin of inner preopercular ridge, and no naked area on anterodorsal surface of body. Therefore, E. gomorah is regarded as a junior synonym of L. splendens.

Both E. ovalis (Fig. 10D) and E. simplex (Fig. 10E) were originally described by De Vis (1884) based on several specimens from Cape York, Queensland, Australia. Although some differences in morphology between these two species can be found in the original descriptions, e.g., scales large in E. ovalis (vs. short in E. simplex), lower margin of preopercle distinctly serrated in E. ovalis (vs. serrated in $E$. simplex), angle formed by lower jaw $40^{\circ}$ in E. ovalis (vs. $45^{\circ}$ in E. simplex), Whitely (1932) designated the lectotypes of both species and stated that he found no characters to maintain the two as distinct species. Therefore, Whitely (1932) regarded E. ovalis was a senior synonym of E. simplex, being distinct from the Indian L. splendens, based on the differences in position of mouth, body depth, pattern of lateral line, and head profile. Subsequently, Munro (1960) and Jones (1985) synonymized E. ovalis and E. simplex under $L$. splendens. From the present examination of the types of $E$. ovalis and E. simplex, we conclude that the two species are junior synonyms of L. splendens as stated by Munro (1960) and Jones (1985), because they have a relatively lower body depth (42-48\% SL in E. ovalis; 46-47\% SL in E. simplex), serrated inner ridge of preopercle, and robust second spine of dorsal fin (width: $0.87-1.6 \%$ of SL in E. ovalis; $1.1 \%$ of SL in E. simplex), although the black markings on dorsal fin were obscure for all specimens.

Leiognathus spilotus was originally described by Fowler (1904) based on a single juvenile $(25 \mathrm{mmSL})$ collected from Padang, Sumatra, Indonesia (Fig. 10F). Because the holotype has the lower margin of orbit located above the horizontal through the gape when mouth closed and a dark blotch on top of spinous dorsal fin, the species undoubtedly belongs to the L. splendens complex. Furthermore, the holotype can be regarded as conspecific with L. splendens because it has a black blotch on the upper spinous dorsal 
fin (nearly indistinct) and serrated inner edge of preopercle.

Leiognathus philippinus (Fig. 10G) was established by Fowler (1918) based on the holotype and four paratypes collected from Philippines, being distinct from L. splendens in body color. After that, James (1978) synonymized $L$. philippinus under L. splendens without explanation. The present examination of the holotype and paratypes of $L$. philippinus confirmed that the species is a junior synonym of L. splendens, based on a jet black blotch on spinous dorsal fin, robust second spine of dorsal fin (width: $1.1-1.3 \%$ of SL), no naked area on nape, and relatively lower body depth (46-48\% SL). Additionally, it should be noted that Fowler (1918) regarded L. jonesi as L. splendens.

Comparisons. Leiognathus splendens is easily distinguished from L. jonesi in having a jet black blotch on dorsal fin (vs. paler dark blotch in the latter; Fig. 4), dull pale to dark yellow lateral line scales if fresh (vs. prominent yellow), anterior dorsolateral surface almost completely scaled (vs. a semicircular naked area on nape; see Fig. 2), and robust dorsal and anal fin spines (width of second spines of dorsal and anal fins $0.87-1.6 \%$ of SL and $0.76-1.7 \%$ of SL, respectively, vs. $0.72-1.1 \%$ of SL and $0.60-0.95 \%$ of SL, respectively; Fig. 5), and is distinguished from L. rapsoni in lacking scales on cheek and interspace of pelvic keels (vs. scales present on cheek and interspace of pelvic keels in the latter; Figs. 2,3). Leiognathus splendens is also distinguished from L. kupanensis sp. nov. in having almost completely scaled anterior dorsolateral body surface (vs. widely naked anterior dorsolateral body surface; Fig. 2).

Acknowledgments We are deeply indebted to K. Mochizuki (Natural History Museum and Institute, Chiba, Japan) for providing critical support to the first author for the study of leiognathids, to R. Pethiyagoda (Ministry of Environment \& Natural Resources, Sri Lanka) for his attempt to examine the types of Leiognathus jonesi, and K. Ikejima (Asian Institute of Technology, Thailand) for donation of Thai specimens. We are grateful to the following persons and institutions for specimen loans: M. McGrouther (AMS); J.G. Lundberg and M. Sabaj (ANSP); K.-T. Shao (ASIZ); J. Maclaine (BMNH); W.N. Eschmeyer and D. Catania (CAS); A. Graham (CSIRO); I. Nakamura (FAKU); G. Duhamel, P. Pruvost, R. Causse, and C.J. Gregorio (MNHN); K. Matsuura and G. Shinohara (NSMT); J. Johnson (QM); M.J.P. Oijen and K. Egmond (RMNH); H.-L. Wu (SFU); F. Krupp, J. Stecher, and H. Zetsche (SMF); D.W. Nelson (UMMZ), J.M. Clayton (USNM); M. Hayashi and K. Hagiwara (YCM); and P.K.L. Ng and K.K.P. Lim (ZRC). We also thank T. Yamashita (a previous student of FRLM) and H. Motomura (AMS) for their help in examination of specimens and collecting literature. This study was supported in part by Grants-in-Aid for Scientific Research (C) awarded to S.K. by the Japan Society for the Promotion of Science (14540642), by the Core University Program of the Japan Society for the Promotion of Science (Biodiversity Studies in the coastal areas of South East Asia), by the Multilateral Cooperative Research Program of the Japan Society for the Promotion of Science (Coastal Oceanography), by Global Environment Research Fund of the Ministry of Environment, Government of Japan, and by N.S.F. grant DEB-0413441 to P.V.D.

\section{Literature Cited}

Abe T, Haneda Y (1972) Description of two new species of the ponyfish genus Leiognathus from Indonesia. Sci Rep Yokosuka City Mus 19:1-6, pl 1

Cuvier GL (1829) Le règne animal distribué d'après son organisation, pour servir de base à l'histoire naturelle des animaux et d'introduction à l'anatomie comparée. Poissons, 2nd edn. Mem Mus Hist Nat 2

Cuvier GL, Valenciennes A (1835) Histoire Naturelle des Poissons, vol 10. Chez FG Levrault, Paris

Day F (1876) The fishes of India; being a natural history of the fishes known to inhabit the seas and fresh waters of India, Burma, and Ceylon. Fishes India Part 2:169-368, pls 41-78

De Vis CW (1884) New fishes in the Queensland Museum. Proc Linn Soc N S W 9:537-547

Fish Team of the Trang Project (2002) Illustrated fish fauna of a mangrove estuary at Sikao, southwestern Thailand. Trang Project for Biodiversity and Ecological Significance of Mangrove Estuaries in Southeast Asia, Rajamangala Institute of Technology and the University of Tokyo, Trang and Tokyo

Fowler HW (1904) A collection of fishes from Sumatra. J Acad Nat Sci Phila (Ser 2) 12:495-560, pls 7-28

Fowler HW (1918) New and little-known fishes from the Philippine Islands. Proc Acad Nat Sci Phila 70:2-71

Gloerfelt-Tarp T, Kailola PJ (1984) Trawled fishes of southern Indonesia and northwestern Australia. Australian Development Assistance Bureau (ADAB), Directorate General of Fisheries, Indonesia (DGF) and German Agency for Technical Cooperation (GTZ)

Hubbs CL, Lagler JF (1947) Fishes of the Great Lakes region. Bull Cranbrook Inst Sci 26:1-186

James PSBR (1971) A new species of silver-belly, Leiognathus jonesi (Family Leiognathidae: Pisces) from the Indian Seas. J Mar Biol Assoc India 11:316-319

James PSBR (1978) A systematic review of the fishes of the family Leiognathidae. J Mar Biol Assoc India 17:138-172

James PSBR (1984) Leiognathidae. In: Fischer W, Bianchi G (eds) FAO species identification sheets for fishery purposes. Western Indian Ocean (Fishing Area 51), vol 2. FAO, Rome

Jones G (1985) Revision of the Australian species of the fish family Leiognathidae. Aust Mar Freshw Res 36:559-613

Iwatsuki Y, Djawad MI, Burhanuddin AI, Motomura H, Hidaka K (2000) A preliminary list of the epipelagic and inshore fishes of Makassar (= Ujung Panang), South Sulawesi, Indonesia, collected mainly from fish markets between 23-27 January 2000, with notes on fishery catch statistics. Bull Fac Agric Miyazaki Univ 47:95-114

Kimura S, Peristiwady T (2000) Leiognathidae. In: Matsuura K, Sumadhiharga OK, Tsukamoto K (eds) Field guide to Lombok Island. Identification guide to marine organisms in seagrass beds of Lombok Island, Indonesia. Ocean Research Institute, University of Tokyo, Tokyo, pp 210-229

Kimura S, Dunlap PV, Peristiwady T, Lavilla-Pitogo CR (2003a) The Leiognathus aureus complex (Perciformes: Leiognathidae) with the description of a new species. Ichthyol Res 50:221-231

Kimura S, Peristiwady T, Suharti SR (2003b) Leiognathidae. In: Kimura S, Matsuura K (eds) Fishes of Bitung, northern tip of Sulawesi, Indonesia. Ocean Research Institute, University of Tokyo, Tokyo, pp 8284

Kühlmorgen-Hille G (1974) Leiognathidae. In: Fischer W, Whitehead PJP (eds) FAO species identification sheets for fishery purposes. Eastern Indian Ocean (Fishing Area 57) and Western Central Pacific (Fishing Area 71), vol 2. FAO, Rome 
Leviton AE, Gibbs RH Jr, Heal E, Dawson CE (1985) Standards in herpetology and ichthyology: Part 1 . Standard symbolic codes for institutional resource collections in herpetology and ichthyology. Copeia 1985:802-832

Mansor MI, Kohno H, Ida H, Nakamura HT, Aznan Z, Abdullah S (1998) Field guide to important commercial marine fishes of the South China Sea. Marine Fishery Resources Development and Management Department, Southeast Asian Fisheries Development Center, Kuala Terengganu, Malaysia

McFall-Ngai MJ, Dunlap PV (1984) External and internal sexual dimorphism in leiognathid fishes: morphological evidence for sexspecific bioluminescent signaling. J Morphol 182:71-83

Mohsin AKM, Ambak MA (1996) Marine fishes and fisheries of Malaysia and neighboring countries. Universiti Pertanian Malaysia Press, Selangor Darul Ehsan, Malaysia

Munro ISR (1960) Handbook of Australian fishes. Fish Newsl 33:133136

Munro ISR (1964) Additions to the fish fauna of New Guinea. Papua New Guinea Agric J 16:170-171

Russell P (1803) Descriptions and figures of two hundred fishes; collected at Vizagapatam on the coast of Coromandel, vol 1. W Bulmer \& Co, London

Senou H (2002) Leiognathidae. In: Nakabo T (ed) Fishes of Japan with pictorial keys to the species, English edition. Tokai University Press, Tokyo, pp 809-812
Shen S-C (1993) Leiognathidae. In: Shen S-C (ed) Fishes of Taiwan. National Taiwan University, Taipei, pp 342-346

Shen S-C, Lin W-W (1985) Study on the leiognathid fishes of Taiwan. Bull Inst Zool Acad Sin 24:125-138

Singh R, Talwar PK (1978) On a new species of silver-belly, Leiognathus indicus Pisces: Leiognathidae [from the Bay of Bengal]. Bull Zool Surv India 1:275-277

Uyeno T, Yabumoto Y (1984) Leiognathidae. In: Masuda H, Amaoka K, Araga C, Uyeno T, Yoshino T (eds) The fishes of the Japanese archipelago, English edition. Tokai University Press, Tokyo, pp 158-159

Weber M, de Beaufort LF (1931) The fishes of the Indo-Australian archipelago, vol 6. Perciformes (continued) Family: Serranidae, Theraponidae, Sillaginidae, Emmelichthyidae, Carangidae, Rachycentridae, Pomatomidae, Lactariidae, Menidae, Leiognathidae, Mullidae. EJ Brill, Leiden

Whitely GP (1932) Some fishes of the family Leiognathidae Mem Queensl Mus 10:99-116

Woodland DJ, Premchaoen S, Cabanban AS (2001) Leiognathidae. In: Carpenter KE, Niem VH (eds) FAO species identification guide for fishery purposes. The living marine resources of the Western Central Pacific, vol 5, bony fishes part 3 (Menidae to Pomacentridae). FAO, Rome, pp 2792-2823

Zheng W-L (1962) Leiognathidae. In: Inst Zool Acad Sinica, Inst Oceanol Acad Sinica, Shanghai Fish Col (eds) The fishes of South China Sea. Science Press, Beijin, pp 438-455 